\title{
Religion og medier i et religionsvidenskabeligt perspektiv
}

\author{
LAURA FELDT \& ARMIN W. GEERTZ
}

ENGLISH ABSTRACT: The religion and media field has grown strongly as an academic subject in recent years, especially regarding studies of religion in contemporary mass media, TV, film, internet, social media etc., and in relation to popular culture. Scholars of religion have also begun to pay attention to the important role that media, mediation, and mediatization have played in the history of religions. It is this growing awareness that we wish to examine here. Our focus is not intended to signal the abandonment of interest in contemporary religion, media and popular culture; rather we wish to place this development in the deep and broad perspective of the study of religion. Media, mediation, and the more recent phenomenon of mediatization, are processes that are inseparable from the ways in which religion functions and is passed on from generation to generation. Thus, from a general study of religion perspective, we promote the argument that media and mediation processes are central aspects of how all religions function because all communication, including religious communication, can be seen as mediated. In this article, we reflect on and discuss the roles that media have played in the deep history of religions and continue to play in the present by bringing religion and media studies in conversation with cultural evolution and cognitive perspectives.

DANSK RESUMÉ: Religion og medier er blomstret stærkt op som emnefelt $i$ de seneste år, særligt med fokus på religion i samtidens massemedier, tv, film, internet, sociale medier m.m. og i relation til populærkultur. Samtidigt er religionsforskere blevet opmærksomme på at medier og mediering har spillet vigtige roller for religionshistorien og det er dén udvikling vi her vil gribe fat $i$. Dermed ønsker vi ikke på nogen måde at signalere en opgiven af interessen for religion, medier og populærkultur i samtiden, men snarere at vi ønsker at indsætte denne udvikling $i$ et langt og bredt religionsvidenskabeligt perspektiv. Medier og mediering er uadskilleligt fra hvordan religion fungerer og viderefores fra generation til generation. Derfor anlægger vi det overordnede perspektiv her, at medier og mediering udgør centrale aspekter af hoordan alle religioner fungerer, da al kommunikation, inklusiv religiøs kommunikation, kan anskues som medieret. I denne artikel reflekterer vi over og diskuterer den rolle medier, mediering og medialisering har spillet $i$ religionshistorien og $i$ samtiden bl.a. med inddragelse af kulturevolutionære og kognitive perspektiver. 
KEYWORDS: religion; media; mediation; history; cognition; evolution.

\section{Indledning}

Religion og medier er blomstret stærkt op som emnefelt i de seneste år, særligt med fokus på religion i samtidens massemedier, $\mathrm{tv}$, film, internet, sociale medier $\mathrm{m} . \mathrm{m}$. og i relation til populærkultur. Nye begreber som medialisering, religion online versus online religion m.fl. har vundet udbredelse både inden for og uden for religionsvidenskab. Samtidigt er religionsforskere blevet opmærksomme på at medier og mediering har spillet vigtige roller for religionshistorien og det er dén udvikling vi her vil gribe fat i. Dermed ønsker vi ikke på nogen måde at signalere en opgiven af interessen for religion, medier og populærkultur i samtiden, men snarere at vi ønsker at indsætte denne udvikling i et langt og bredt religionsvidenskabeligt perspektiv. Snarere end snævert at forstå en interesse for religion og medier som noget der muliggør analyser af religion, populærkultur og medier i samtiden, tager vi her fat i den lange religionshistorie og diskuterer, hvordan medier og mediebrug har gjort en forskel for religioner og religiøse forandringer i både fortid og nutid. Selvom ofte anvendte perspektiver på religion har angået spørgsmål om ideer, forestillinger, kommunikation og repræsentationer, så har forskningsfeltet religion og medier været med til at kaste lys på, at medier, deres brug, materialitet, status og appel ikke er noget der fungerer i tillæg til religion. Medier og mediering er uadskilleligt fra hvordan religion fungerer og videreføres fra generation til generation. Derfor anlægger vi det overordnede perspektiv her, at medier og mediering udgør centrale aspekter af hvordan alle religioner fungerer, da al kommunikation, inklusiv religiøs kommunikation, kan anskues som medieret. I religioner anvendes således mange forskellige medier fra fx litteratur, ritualer, kropsteknologier, til arkitektur, tingeltangel og nips, tøj, udsmykning, kunst, figurer, statuer, fotografier, film, blogs, youtube-videoer og sociale medier. De anvendes i forskelligt omfang, i forskellige kontekster og med forskellig værdisætning og statustilskrivning, ligesom deres brug både afspejler og påvirker de samfundsmæssige kontekster som religionerne udgør en del af, og de er med til at forme hvordan religionerne opleves, sanses, og forstås af tilhængerne og i samfundet i bredere forstand. I denne artikel vil vi reflektere over og diskutere den rolle medier, mediering og medialisering har spillet i religionshistorien og i samtiden med bl.a. inddragelse af kulturevolutionære og kognitive perspektiver. Men først giver vi en introduktion til teorier om religion og medier ${ }^{1}$ samt centrale begrebsafklaringer, før vi bevæger os til teorier om kulturel evolution.

1 Dele af denne indledende præsentation overlapper med Feldt (2019). 


\section{Religion og medier - medier og religion}

I de sidste 30 år er et bredt og interdisciplinært felt som vi kan kalde religion og medier vokset frem; her bidrager både religionsforskere, medieforskere, sociologer, antropologer med flere. Feltet har primært fokuseret på nye medier såsom internetbårne sociale medier, tv-serier, film, digitale spil og nyhedsmedier i perioden fra midt 1990erne og til i dag (se fx Clark 2003; Hjarvard \& Lövheim 2012; Campbell \& Grieve 2014; Hoover 2016; m.fl.). Det er således i dette blomstrende felt at teorier om religionens medialisering (Hjarvard 2008a. 2008b. 2011. 2012), om religion online versus online religion (Dawson \& Cowan 2004), er vokset frem, og der findes i dag en velorganiseret struktur med årlige konferencer og en stadig strøm af udgivelser inden for området som i dag primært er kendt som 'media, religion and culture'-feltet efter selskabet af samme navn. ${ }^{2}$ Området overlapper i et vist omfang med 'religion and popular culture'-feltet. Medier, religion og kultur-feltet har fokuseret på medialisering som et særligt moderne eller senmoderne fænomen og interesseret sig for strukturelle ændringer i kommunikationsindustrien og medieteknologier, samt for massemedier og i særlig grad for digitale medier (Morgan 2011, 137). Selvom denne dominerende interesse lige så stille er ved at blive udvidet til bredere analyser af religion og medier (Meyer 2011; Lundby 2013; Horsfield 2015; Feldt \& Høgel 2018; Feldt \& Bremmer 2019), så synes det rimeligt at påpege at der savnes medie-fokuserede analyser der arbejder ud fra religionernes lange og brede historie, ligesom feltet generelt synes at mangle historiske perspektiver og komparative analyser også af globale religiøse konstellationer. Vi argumenterer her for at studiet af religion og medier naturligvis bør inkludere religionshistorien bredt og komparativt, og af samme grund kan studiet af religion og medier kobles til teorier om kulturel evolution og kognition. Vi tilslutter os Morgans forslag om at medialiseringsteorien skal indlejres i en bredere medieringsteori (Morgan 2011, 138) ${ }^{3}$ samt Meyers teoretisering af religion som grundlæggende medieret (Meyer 2011; 2014). Før vi diskuterer religion og medier i denne bredere forstand vil vi imidlertid kort præsentere udvalgte teorier vedrørende religion, medier og populærkultur i samtiden, om medialisering og digitalt medieret religion, før vi bevæger os til det bredere perspektiv.

De teorier der berører det religiøse felt i samtiden stammer som sagt hovedsageligt fra det blomstrende felt "media, religion and culture", hvor man også er optaget af hvordan medier gør en forskel for religiøse forandringer, og af hvordan religion i medier og populærkultur afspejler og påvirker det religiøse felt (Dawson \& Cowan 2004; Forbes \& Mahan 2005; Lynch, Mitchell \& Strhan 2011; Lyden and Mazur 2015). Stig Hjarvards teori om religionens medialisering er nok en af de mest kendte teorier inden for feltet både i Danmark og internationalt. Hjarvards teori er indlejret i en forståelse af den mediehistoriske udvikling i de nordiske lande som en bevægelse hen-

2 Organiseret af selskabet International Society for Media, Religion and Culture https://www.colorado.edu/cmrc/resources/international-society-media-religion-and-culture. Se også Grodal 2009; Hadden \& Cowan 2000; Højsgaard \& Warburg 2005.

3 NB: Hjarvard skelner også mellem medialisering og mediering (2008a; 2008b, 13-14; 2011; 2012, 26). 
imod selvstændige medie-institutioner, hvor vi i dag ser 'medier' som er selvstændige samfundsaktører på den ene side og på anden side også er indlejrede i alle øvrige samfundsinstitutioners virke. Medialisering betyder således kort sagt denne dobbeltsidede proces, hvor medierne udvikler sig til en selvstændig samfundsinstitution og samtidigt bliver en integreret del af andre samfundsinstitutioner (Hjarvard 2012, 2426). ${ }^{4}$ Det betyder at religiøs kommunikation nu foregår 'på mediernes præmisser', dvs. underlagt mediemæssige teknologiske, kommercielle og genremæssige krav. ${ }^{5}$ Hjarvard udpeger at det generelt betyder tab af autoritet og magt for traditionelle religionsformer og -aktører og generelt en mere forbrugerorienteret og individualistisk tilgang til det religiøse felt, til religiøst indhold og religiøs kommunikation (Hjarvard 2012, 31-32). Ifølge Hjarvard betyder religionens medialisering således en form for sekularisering. ${ }^{6}$ Hjarvards udgangspunkt er det tilsyneladende paradoks vi ser i de skandinaviske lande, nemlig at religion er ganske et nærværende og påtrængende tema i medierne, mens vi samtidigt ser en faldende tilslutning til traditionel, institutionaliseret religion (Hjarvard 2012, 27). Hans teori søger at forklare religions tilstedeværelse i medierne på den baggrund og undersøger, hvordan medierne er blevet formidlere og producenter af religiøst indhold og har overtaget nogle af de funktioner, som religion tidligere varetog. Hjarvards teori præsenterer forskellige typologier for former for medialiseret religion (religiøse medier, journalistik om religion, og banalreligion, hhv. medier som kanaler, sprog, miljø; Hjarvard 2012), ${ }^{7}$ som er blevet anvendt i feltet (se fx øvrige artikler i Hjarvard \& Lövheim 2012). At religion er blevet medialiseret betyder således her at religion repræsenteres i journalistik om religion ud fra journalistiske kriterier om nyhedsværdi og konflikt og i populærkultur som banalreligion, ${ }^{8} \mathrm{dvs}$. religiøse repræsentationer der fungerer på mediernes præmisser om salgbarhed og underholdningsværdi (se fx den skematiske oversigt i Hjarvard 2012, 40). Hjarvards teori fokuserer således på de særlige sociale betingelser for religion i samtiden. Som Lynch har påpeget så gælder det særligt for de nordiske lande at mainstream-medierne ikke som sådan er konfessionelle, at der findes ganske få decideret konfessionelle medier, at befolkningen i bred forstand har et forholdsvist

4 Morgan peger på, at en lignende udvikling ift. mediernes autonomi kan ses allerede i 1400-tallet, hvor bog- og pamflet-produktion i Europa overgik til kommercielle aktører (Morgan 2011, 141).

5 Disse varierer naturligvis alt efter medie (se her Hjarvard 2012).

6 Jf. en variant af differentieringstese-typen, evt. de-intensifiserings-tese-typen, i Woodhead og Heelas' firfoldige typologi over typer af sekulariseringsteorier (Heelas \& Woodhead, eds., 307).

7 Denne typologi stammer oprindeligt fra Meyrowitz 1986.

8 Hjarvard forstår banalreligion som en bricolage af overnaturlige / religiøse elementer fra traditionelle religiøse kontekster, der tjener andre formål end religiøse institutioners og som ikke decideret er en del af bestemte religioners verdener eller religiøse kommunikation. Forskellige elementer forekommer blandet sammen og banalreligion går ofte 'under radaren' ift. samfundsdiskurser og italesættelser af religion; men banalreligion fungerer alligevel som en slags bagtæppe af religiøsitet i samfundet (Hjarvard 2012, 35-39). Bemærk at termen ikke er pejorativt intenderet; den refererer til Michael Billigs begreb 'banalnationalisme', som skal referere til omfattende men ubemærkede symboler og handlinger, der understøtter individers nationale tilhørsforhold og national kultur (Hjarvard 2012, 35). I et religionsvidenskabeligt perspektiv er der visse overlap med den religiøsitet som kaldes 'nyspiritualitet' (Heelas \& Woodhead 2004; Ahlin 2008), selvom det bør understreges at termerne ikke udpeger samme felt. 
lille aktivt og eksplicit engagement i religiøse institutioner, og at der er en samfundsmæssig situation præget af én stor, tydeligt identificérbar og statsligt privilegeret religiøs institution (de protestantiske kirker), samtidigt med en høj grad af samfundsmæssig og individuel sekularisering (Lynch 2011, 205). Det gør, udpeger Hjarvard, at mainstream-medierne for mange bliver en primær kilde til information om og oplevelse af religion, religiøse fortællinger og -symboler. Ganske få mennesker benytter sig af decideret religiøse medier, og det betyder at den brede befolkning møder religion i journalistik om religion og som banalreligion.

Hjarvards teori er blevet kritiseret for at mangle kompleksitet ift. forståelse af religionshistoriske forandringer globalt og i den lange religionshistorie og således passe bedst til skandinaviske forhold i samtiden (hvilket Hjarvard undervejs også har medgivet, jf. Hjarvard 2012), for at mangle kompleksitet ift. brugen af medier i andre institutioner, hvor medielogikker kan underordnes andre institutioners logik (fx en skolelogik, Lied 2012), og for at levne for lidt plads til (religiøse) aktørers og gruppers handlinger (Lövheim 2011), ligesom Morgan har fremhævet at protestantisk bog- og pamfletproduktion i det 18. og 19. århundrede påvirkede 'medie'-logikker og ikke omvendt (Morgan 2011). Samlet set går en del af kritikken altså på, at det er for enkelt og unuanceret at placere forandrings-agens alene i medieinstitutioner og -teknologier, og på manglende religionsvidenskabelig og historisk kontekstualisering.

Denne kritik er på flere måder velplaceret. Men vi vil her især pege på teoriens implicitte religionsforståelse som mangelfuld og som noget der for en religionsvidenskabelig betragtning begrænser dens analytiske værdi, idet en protestantisk, institutionaliseret religionsform anskues som indbegrebet af 'religion', hvilket betyder et overdrevent fokus på tro, doktriner, institutioner og sammenhængende verdenssyn. Det betyder at andre religionstyper samt uofficielle, folkelige og levende religionsformer for religion til dels ignoreres, til dels ikke anses for at være rigtig religion, og/eller til dels ikke ses i komparativ belysning. Endvidere er det vigtigt at påpege at den implicitte forståelse af religion som et oprindeligt umedieret felt er urealistisk, og at religion og medier er grundlæggende sammenflettede. På trods af disse indvendinger har Hjarvards medialiseringsteori bestemt en frugtbar udsagnskraft og et nyttigt analytisk potentiale netop for visse former for forandringer i det religiøse landskab i skandinaviske lande i perioden fra 1980erne og frem. Men medialiseringsteorien bør indlejres i bredere teorier om religion og medier, for hvis medialisering er en slags 'media-makeover' af religion, så er det jo tydeligvis noget der er sket mange gange før i verdenshistorien (Morgan 2011, 140-141). Det vender vi tilbage til.

Teorien om religionens medialisering fører os først videre til en kort diskussion af internettet og digitale medier, som for alvor blev udbredt i Skandinavien og globalt i anden halvdel af 1990erne. Dawson og Cowan har opsummeret hvordan de nye internetbårne og digitale medier gør en forskel for det religiøse felt. De peger kort sagt på at udbredelsen af internettet og digitale medier generelt muliggør en større pluralisme (og et bredere alment kendskab til pluralismen) i det religiøse felt og en deraf 
følgende relativering af sandhedspostulater. ${ }^{9}$ Endvidere ser vi mere religiøs kommunikation og praksis uden om religiøse autoritetspersoners kontrol, mindre præcision i afgrænsningen af den religiøse gruppe og mere elastik i afgrænsningen af religiøst indhold som nogle af de centrale træk (Dawson \& Cowan 2004; Cowan 2011). Generelt betyder dette også individualisering, relativering og i det hele taget mere gør-detselv-religion. Cowan og Dawson introducerer en skelnen mellem religion online, som henviser til det faktum at alle de traditionelle, organiserede religioner i dag også er til stede online og på digitale medier, og online religion, som er en betegnelse for religiøs kommunikation og praksis som alene findes og praktiseres online (Dawson \& Cowan 2004) - en skelnen som er nyttig, også selvom grænserne mellem de to nogle gange kan være uklare empirisk. Ift. online religion rejser der sig nogle interessante metodiske og teoretiske problematikker (jf. Dawson 2004) vedr. autenticitet (anser vi det stadig for religion, når ingen kroppe er fysisk forsamlede i et ritual? - og vi kan ikke altid vide om informationer på nettet er opspind, 'pranks' eller leg), vedr. gruppernes omfang og stabilitet over tid (mange rent digitale religiøse grupper forandrer sig hastigt og/eller dør hastigt ud), samt ift. autoritet (ofte er det svært at lokalisere konkrete brugere/aktører/autoritetspersoner bag hjemmesider og digitale medier, jf. Cowan 2011; jf. medie- og materialitetsperspektiver på autoritet: Feldt \& Høgel 2018).

Endvidere er online religion nogle gange koblet multimedialt til religion i populærkultur. Her er brugen af religiøse udtryk i film og tv-serier - som fx The Game of Thrones, Vikings, Magicians, Star Wars, Harry Potter og Ringenes Herre osv., bare for at nævne nogle ganske få - ofte så omfattende og betydningsbærende at de ikke kan forstås blot som ubetydelige underholdningselementer eller ikke-religion, selvom de blandes med leg og forbrugerisme i produktions- og receptionskulturerne. Disse flydende grænser følger nogle gange med på internet og digitale medier; andre gange kan 'fiktionsbaserede religioner' udvikle sig (jf. Davidsen 2013).

Multimedial kommunikation om og brug af religiøse udtryk i samtiden forstærker religiøse elementers fascinationskraft yderligere og kan give selv fritsvævende religiøse udtryk, som ikke har nogen forankring i traditionelle, organiserede religioner med institutioner, kanon, hierarkier og ritualer, en social betydningsfuldhed via deres enorme udbredelse (Feldt 2016). De er religionsvidenskabeligt interessante, fordi de afspejler forandringer i holdninger til religion, i brug af religion og i religions status i samtiden, og fordi de informerer, afspejler og påvirker religiøse interesser og religiøs fascination i samtiden og tilvejebringer en arena for udforskning af religiøse ideer, meninger, følelser og holdninger til det religiøse. ${ }^{10}$ Denne udvikling spiller selvfølge-

9 Dette kan ses i sammenhæng med hvad Michael Saler har påpeget vedr. en vestlig afslappethed ift. og accept af verdenskonstruktioners og -fortolkningers kontingens. Væksten i det som Saler kalder de nye virtuel-reality og fantasy-offentligheder, betyder at vestlige offentligheder i stadigt højere grad accepterer at 'virkelighed' er en foranderlig konstruktion (Saler 2012, 3-23), og at vi snarere taler om "a willing activation of pretense" end om Coleridge's (i fantasyforskningen klassiske) "willing suspension of disbelief" (Saler 2012, 28-32).

10 Som Laura Feldt har påpeget andetsteds (2016) og i lighed med hvad der finder sted $\mathrm{i}$ andre medier som fx skønlitteratur (jf. Feldt 2009). 
lig sammen med andre samfundsmæssige forandringer i nutiden, hvor religionssociologer har påpeget effekterne af en subjektiv vending inden for religion i Europa, hvor personlig udvikling og 'spiritualitet ${ }^{11}$ står centralt; dette har betydet at religionsformer (og i europæisk sammenhæng: særligt kristendomsformer) der ikke vægtlægger eller har fokus på en personlig, åndelig udvikling, oplever nedgang (Woodhead \& Heelas 2003; Woodhead 2004, 330-360; Partridge 2004-2006; Lyon 2000). Denne udvikling indikerer også at forholdet mellem religion og medier er ganske komplekst og sammenvævet på forskellige måder med en given samfundsmæssig og historisk kontekst.

Som tidligere fremhævet så vil vi altså her - inspireret af nyere tendenser i religion og medier-feltet (Meyer 2009, 2011; Morgan 2012; Stolow 2005; Lundby 2013) - arbejde ud fra antagelsen om at medier og deres brug, materialitet, værdisætning og appel er uadskilleligt sammenvævet med religion, religiøs kommunikation og praksis, dvs. til hvordan religion fungerer i samfund og for individer. I dette perspektiv anvender alle religioner og former for religiøsitet således medier af mange forskellige slags for at sikre transmissionen til andre, herunder de næste generationer, dvs. for ikke at dø ud. Al religion er således altid medieret på flere forskellige måder og anvender og værdisætter forskellige medier forskelligt. ${ }^{12}$ Alligevel har udviklingen i nyere tid med fremkomsten af nye medier, massemedier og den såkaldte 'mediealder' stået i centrum i forskningen, og religion og medier er i nogle sammenhænge blevet forstået som separate sfærer (jf. Hoover 2016a, xiii). Men det er en uholdbar teoretisk position, eftersom sammenhængene mellem religion, medier og kultur har relevans for alle menneskelige samfund, og de handler om meget mere end religion i moderne nyheds- og massemedier (jf. Hoover 2016b, 1-11). I stedet bør religion og medier ikke anskues som separate sfærer, men som grundlæggende forviklede. Det er især antropologen Birgit Meyer og religionshistorikeren David Morgan, som har været primus motorer i at sætte en ny dagsorden, hvor religion studeres som grundlæggende medieret og hvor man kigger på hvorledes medier anvendes i religion for at sikre transmission og fastholdelse, bl.a. ved at give en fornemmelse eller erfaring af og former for adgang til "something beyond" (Meyer 2014, 214; 2008). Mediering anskues således som helt integreret i religiøs praksis (Meyer 2014; Morgan 2012; Stolow 2005).

Her bygger vi på sådanne perspektiver om at medier og deres brug, værdisætning og indflydelse er uadskillelige fra hvordan religion kommunikeres, reproduceres, fungerer og forbliver effektiv og vi søger at integrere dem med kulturevolutionære og kognitive perspektiver på den lange og brede religionshistorie. Af den grund arbejder vi med en bred forståelse af mediering og medium med inspiration fra Birgit

11 Spiritualitet italesættes som fundamentalt forskelligt fra religion af aktører i feltet; det betyder selvfølgelig ikke at spiritualitet nødvendigvis falder uden for en etic-religionsdefinition. Distinktionen kan genfindes i mainstream fantasylitteratur, hvor traditionel religion fremstilles som impotent og forstenet, mens magi og spiritualitet fremstilles som potent og spændende (Kelso 2007, 65-66. 70. 7175).

12 Morgan diskuterer fx (groft opsummeret) katolsk visuel og kropslig religiøsitet over for et protestantisk fokus på ører, hørelse og ord (Morgan 2012). Se også Lundager Jensen 2020, der også anlægger et langt og bredt religionshistorisk perspektiv inspireret af Sloterdijk og Bellah. 
Meyer og Joshua Meyrowitz. Her forstår vi medier som former og apparater der fremmer kommunikation og muliggør relationer, inklusive sociale strukturer og traditioner (jf. Feldt 2016a, 5-6); dvs. at al kommunikation anskues som medieret. Dermed afviser vi også flere almindelige medieforståelser, som $\mathrm{fx}$ forestillingen om en oprindelig, umedieret kulturtilstand, det instrumentelle syn på medier som neutrale kommunikationskanaler, og endelig det teknologisk deterministiske synspunkt som tildeler medier en meget stor virkekraft og vilje (Hoover 2016, xiv; Feldt 2019). Selvom forskellige medier inviterer til forskellige former for interaktion og brug (dette kunne man evt. kalde affordances ${ }^{13}$ ), så eksisterer der altid en mulighed for at aktører i en given sammenhæng kan vælge at bruge medier kreativt og taktisk. ${ }^{14}$ Selvom definitioner af medier og mediering er meget omdiskuterede, argumenterer vi altså for at historiske medieanalyser er bedst tjent med sådanne brede medieforståelser som muliggør komparative diskussioner. Så selvom man ofte tænker på medier som et moderne fænomen som fx radio, tv, film, facebook og twitter, er det afgørende for en religionsvidenskabelig tilgang at understrege at det er en alt for snæver forståelse. På den ene side er al kommunikation medieret - fra tale til krop, skrift, dans og billeder, osv. - og derfor er det på den anden side afgørende at få inkluderet en medie-opmærksomhed og et medie-vokabular i det religionsvidenskabelige analysestrategiske kabinet.

Som Regis Debray har påpeget så 'rejser' kommunikation aldrig uændret, for både afsender og modtager forandres af udvekslingen af 'beskeden', ligesom beskeden selv transformeres ved at blive cirkuleret. Medier har som regel en materiel, fysisk eller formmæssig side, og også derfor spiller materialitet og teknologi afgørende roller i medieringsprocesser, fordi materialitet medierer menneskelige relationer i verden (Debray 1996, 44). Medier er derfor ikke neutrale bærere af indhold eller kommunikationskanaler, men kan i endnu bredere forstand end ovenfor anskues for at være 'indhold-i-form' med særlige fysiske, sansemæssige, sociale og teknologiske karakteristika som kan beskrives og analyseres. De medierer ikke kun information, men også følelser og sociale relationer (se næste afsnit). De er også materielle genstande som stimulerer særlige former for brug, relationer og interaktioner (Feldt 2016; 2019). Mediers teknologisk-materielle forudsætninger og aspekter kan fx lagres, udstilles, og brændes; de frigør hukommelseskapacitet fra den menneskelige hjerne, men de fungerer også som udvekslingsgenstande i relationer og er med til at skabe bestemte netværk via adgang og brug. Med Jörg Heider kan vi sige at medier er betinget både internt og eksternt via deres karakteristika; disse kommunikationsbetingelser og karakteristika påvirker receptionen og brugen (Heider 1959; Feldt 2016). Nye medier kan således føre til sociale forandringer over tid ved at konstruere nye identitetsdannelsesmønstre, socialiseringskonventioner og hierarkier, som Joshua Meyrowitz har

13 Begrebet 'affordances' stammer fra psykologen James Gibsons økologiske tilgang til visuel perception, som går ud på at ting, mennesker, situationer, miljøet osv. 'tilbyder' en person mange mulige interaktioner (Gibson 1950. 1969 og især 1979; se Davidsen 2018, 1-11).

14 Se også Meyers diskussion (2011, 23-29). Dette viser religionshistoriske casestudier også; se her fx casestudierne i Feldt \& Bremmer 2019. Distinktionen mellem strategi og taktik stammer fra de Certeau 1984. 
peget på (Meyrowitz 1994, 50-77). Nye medier kan også forstærke eksisterende medieringsprocesser, nå nye publikumssegmenter, eller muliggøre nye former for kontakt over tid og i rum. Hvis vi med Debray anskuer mediering som noget der henviser til komplekse processer gennem hvilke afsendere, budskaber og modtagere forandres i kommunikationshandlingen, via en række materielle genstande eller former for materialitet (som også inkluderer fx kroppe), så bliver det meget klart at medier ikke er neutrale kanaler eller indholdsbærere. Men som det også fremgår, så vil vi med Hoover betone handling og forandring endnu mere tydeligt i relation til mediering (Hoover 2016, xiv) end det tidligere er sket. For selvom medier har karakteristika som påvirker os, og selvom vi agerer inden for bestemte mediekulturer som inviterer til bestemte handlemuligheder og lægger bestemte begrænsninger, så fastholder vi muligheden af at aktører kan handle kreativt og taktisk mhp. forandring (Mahan 2014, 12), ligesom andre aktører og relationer i netværket kan muliggøre emergente forandringer. Dette gælder både i fortid og nutid.

Ovenstående tilgang til medier og mediering betyder også at vi ikke kan isolere studiet af religion og medier i samtiden, men at det på den ene side må tilgås i komparativ diskussion med øvrige religionshistoriske epoker og kontekster. Det vil også på den anden side sige, at medier i samtiden kan analyseres vhja. ovenstående bredspektrede tilgang til medier og mediering. Vi kan således analysere brugen af religion i film eller tv-serier mere nuanceret via en bredere forståelse af medier som 'indholdi-form' og distinktionen om interne hhv. eksterne mediespecifikke karakteristika som ikke bare må klassificeres en gang for alle som 'banalreligion', selvom vi selvfølgelig stadig også skal kigge på bredere effekter, samfundsmønstre og -institutioner og brugskontekster.

Som Liv I. Lied tidligere har peget på, så giver tendensen til at anskue religion-ogmedier-feltet i perioder før trykpressen som noget der var præget af enkelhed, kontrol og lokale kontekster simpelthen et for unuanceret billede, der ikke yder disse historiske mediekulturer retfærdighed (Lied 2013; se her endvidere Lundby 2013 og casestudierne i Feldt \& Høgel 2018; Feldt \& Bremmer 2019). Sådanne perspektiver søger vi yderligere at udfordre her ved at anskue religion og medier i kulturevolutionært og kognitivt perspektiv. Medier taler selvfølgelig ikke med én stemme uafhængigt af kontekst og forskellige medier interagerer ofte på varierende måder i forskellige, historiske mediekulturer. Men vi bruger her ordet mediekultur til at henvise til interaktionen mellem kulturelle og samfundsmæssige faktorer og kommunikationskontekster, hvor nogle former for mediering - og de former for socialt liv de inviterer til - kan dominere og skabe forandringer i nogle perioder og kontekster (Mahan 2014, 12-14). For den lange og brede religionshistorie er forandringer i mediekulturer og samfund som finder sted når mennesker forsøger at bruge, modstå eller adaptere nye medier og medieteknologier (Mahan 2014, 14), såvel som når aktører i bredere netværk skaber forandringer, særligt interessante, ligesom vi er interesserede i større epokale skift. ${ }^{15}$

15 Vi er bevidste om at der er store epokale skift, som er blevet studeret i et frugtbart, mediehistorisk og kommunikationsteknologisk perspektiv, fx fra mundtlig kultur til håndskriftsbaseret og til bogkultur. Disse forandringers kognitive og sociale funktioner, samt deres rolle i religiøse kontekster 


\section{Religionsevolution i et biokulturelt perspektiv}

I denne artikel vil vi gerne bringe diskussionerne af mediers rolle i den lange religionshistorie videre ved at inddrage kulturevolutionære perspektiver for at give et mere nuanceret men også overordnet blik på mediers vigtige rolle i religionernes historie, ikke som en enstrenget, sammenhængende og stadigt fremadskridende eller konsistent udvikling, men som et foranderligt og formbart, men også tværkulturelt komparativt og kumulativt fænomen. Med den nyeste forskning i ryggen kan man hævde at medier som uomgængelige for kommunikation er kernen i homininernes (og dermed Homo sapiens) evolution.

Forståelsen af den menneskelige evolution har ændret sig især siden midten af det 20. århundrede (se fx foregangspublikationen Spuhler \& White 1959; jf. Geertz 2015). Med de mange akkumulerede indsigter inden for arkæologi, genetik, biologi, etologi, komparativ psykologi, lingvistik, neurovidenskaberne og diverse humanistiske hybride videnskaber (som fx biosemiotik, kognitiv lingvistik, kognitiv religionsvidenskab og kognitiv arkæologi) især siden 1980'erne, har en lang række forskere vist, hvorledes den biologiske (genetiske) og kulturelle evolution gensidigt påvirker hinanden. Tre begreber, som er kendetegnende for denne forståelse er 'niche construction', 'gene-culture coevolution' og 'dual-inheritance theory', formuleret af banebrydende forskere som Peter J. Richerson, Robert Boyd (Boyd \& Richerson 1985; Richerson \& Boyd 2004), Kevin N. Laland (Laland 2008, 2017), Luigi Luca Cavalli-Sforza (Cavalli-Sforza \& Feldman 1981; Cavalli-Sforza 2000), Michael Tomasello (Tomasello 1999), Merlin Donald (Donald 1991; 2001) og Terrence Deacon (Deacon 1997). Især Donald og Deacon har haft stor betydning for dansk religionsvidenskab og flere andre fag som fx kognitiv semiotik og kognitiv arkæologi. De har også begge været gæster i Danmark og Donald har være adjungeret professor på religionsvidenskab i Aarhus. Donalds biokulturelle og Deacons biosemiotiske tilgange har haft afgørende indflydelse på Armin W. Geertz's biokulturelle religionsteori (Geertz 2010; 2017; 2018), Jeppe Sinding Jensens normative kognitionsteori (Sinding Jensen 2010; 2013; 2014) og Jesper Sørensens immunologiteori (Sørensen 2004; Sørensen \& Nielbo 2015). Andre som har draget fordel af Donalds arbejde, er Hans J. Lundager Jensen (Lundager Jensen 2005), Anders Klostergaard Petersen (Petersen 2015, 2017), Katrine Frøkjær Baunvig (Baunvig 2017) og Kirstine Helboe Johansen (Johansen \& Baunvig 2014). Merlin Donald har inspireret Robert Bellah i sit storværk Religion in Human Evolution (2011) og dermed også har haft indflydelse på den danske aksetids- og evolutionsforskning (Lundager Jensen 2011; Petersen 2019).

Hvad menes der med 'kulturel evolution' og et biokulturelt perspektiv? I et nyt værk med titlen Menneske, kultur, evolution - et biokulturelt perspektiv (Nielsen et al. 2019) karakteriserer Casper Andersen et al. forholdet som følger:

Kultur er i denne kontekst en biologisk-psykologisk mekanisme hos mennesker, der kommer til udtryk som socialt tillært information, der påvirker et individs adfærd (Ri-

analyseres bl.a. i Dehaene 2009; Dehaene et al. 2010; Goody 1987; Levy 2012; Lundby 2013; Ong 1996; Smith 1985 og Street 1984. 
cherson \& Boyd 2004). Videregivelsen af læring (kulturel transmission) er derved essensen af kulturel evolution (kumulativ kultur) og er en tilpasning, der har indflydelse på den genetiske selektion (Andersen et al. 2019, 24).

Felix Riede og Matthew J. Walsh formulerer det meget rammende:

Kultur er ... biokulturel: Den skabes til dels af biologiske (genetiske, epigenetiske, fysiologiske) processer, og disse processer modificeres og kanaliseres til dels af kulturelle (adfærdsmæssige, materielle, idémæssige, institutionelle) processer. Kultur udvikler sig også i en darwinistisk forstand: Den er et informationstransmissionssystem, hvor generation efter generation af lærere og elever og deres handlingsopskrifter påvirkes af selektion og tilfældigheder. Sådan arv kan være genetisk, kulturel og miljømæssig, og disse arvetypers interaktion skaber med tiden komplekse forandringsmønstre (Riede \& Walsh 2019, 57).

Mennesket har skabt sin egen niche, nemlig kultur. Med denne skabelse har vi delvis - men på afgørende vis - overtaget vores egen biologiske evolution. På grund af menneskets indblanding i egen evolution bliver man nødt til at se nuanceret på den menneskelige evolution. Den biologiske evolution har leveret et væsen som er i stand til at udvikle sociale og kulturelle verdener. Det medfører at individer og grupper underlægges både biologiske og miljømæssige men sandelig også kulturelle og sociale selektionsmekanismer. Vores evolution er derfor både tilfældig (blind) og teleologisk (formålsbestemt).

I bogen The Emergence and Evolution of Religion: By Means of Natural Selection (Turner et al. 2018) har Jonathan H. Turner, Alexandra Maryanski, Anders Klostergaard Petersen og Armin W. Geertz identificeret, hvilke selektionsmekanismer, der kan være på spil i religionens evolution. Baseret på Turners og Maryanskis tidligere arbejde (Turner 2000; Turner, Machalek \& Maryanski 2013; Turner \& Maryanski 2008) har de forsøgt at kombinere biologiske, kulturelle og sociologiske evolutionsteorier. Vi skal her fremhæve to hovedforklaringer, som kaster lys over medier og religion.

Den første hovedforklaring drejer sig om hjernen. Der er to problemer i vores viden om hjernen i menneskets evolution. Det første problem drejer sig om hjernebarken. Man har hidtil hævdet, at homininernes evolution kendetegnes ved den usædvanlige store udvikling af hjernebarken, som til dels skyldes brugen af redskaber og dermed kultur. Man hævder at denne udvikling var hovedårsagen til at homo-arten kunne forlade skoven og overleve på savannen. Men problemet med denne forklaring er, at hjernebarkens udvikling bliver først mærkbart stor i midten af Homo erectus-linjen (linjen varede fra 1.9 millioner år siden indtil 70.000 år siden). Menneskelinjen var med andre ord for længst rejst ud på savannen. En lille fodnote her desuden er, at de tidligste homininer - Australopithecus - var allerede begyndt at bruge primitive stenredskaber for ca. 3-4 millioner år siden (McPherron et al. 2010), altså før homo-linjen. Hvad var det så, der gjorde det muligt for homo-linjen at forlade skoven? Ved at udføre en kladistisk ${ }^{16}$ analyse har antropologen Alexandra Maryanski demonstreret at

16 En kladistisk analyse (også kaldet en fylogenetisk analyse) er en metode til at rekonstruere evolutionære familieforhold eller slægtskaber ud fra varianterne, om det så er sprog, gener eller arter. Metoden bruges til opbygningen af klassifikationssystemer inden for biologi, sprogvidenskab og etnografi. 
en hel anden udvikling var i gang allerede med australopithecinerne igennem flere millioner år, nemlig udviklingen af de subkortikale områder omkring følelseshjernen. Homo sapiens' følelseshjerne er dobbelt så stor som chimpansernes sammenlignet med Tenrecinae - det lille rotte-lignende dyr som angiveligt igangsatte primat-familien for 63 millioner år siden i Afrika (Turner et al. 2018, 82ff.). Vi er med andre ord en hidsig og sex-fikseret art. Et andet hjerneområde som også blev ekspanderet i den pågældende periode, er Brocas-området som medfører kontrol over følelsesudbrud. Brocasområdet findes i chimpanse-hjerner, men er her ikke særligt veludviklet i forhold til menneskehjerner.

Det andet problem drejer sig om social organisering. Maryanski har lavet en kladistisk samt en netværksanalyse af sociale systemer for alle menneskeaber sammenlignet med små aber. Sidstnævnte har meget hierarkiske systemer som gør det muligt for gruppen at begå sig i farlige situationer. Bavianer kan fx godt begå sig på savannen i kortere tid fordi de fungerer nærmest som militære enheder. Men menneskeaberne har - til trods for en veludviklet socialitet - et meget løst socialt system (Maryanski 1992; 1993; 1995; 2013; 2018).

Med disse to problemer in mente, hvordan kunne denne nøgne og forsvarsløse Homo habilis forlade skoven og overleve i savannen? Den første forklaring kommer fra Turner og kolleger, som argumenterer for at udviklingen af følelseshjernen gjorde det muligt at udvikle en følelsespalet som langt overstiger andre arters (Turner et al. $2018,82 \mathrm{ff}$.). Det vil sige, at man udviklede kombinationer af de fire grund-emotioner (vrede, frygt, sorg, glæde) ${ }^{17}$ hvoraf de fleste er negative, til de mere positive og motiverende ('sekundær' eller 'sociale') emotioner som kærlighed, beundring og ærefrygt. Disse udgør det emotionelle grundlag for dannelsen af de første kernefamilieog storfamilie-bander som overlevede savannen gennem solidaritet og parathed til at dø for gruppens skyld. Disse mindre jæger-samler-grupper kunne desuden udvikle og opretholde sammenhold meget effektivt gennem to yderligere emotionskombinationer, nemlig skyld og skam.

Men hvordan blev disse følelsesladede individer forvandlet til sammentømrede, overlevelsesdygtige sociale grupper? Durkheim har for længst påvist at sammenholdet regelmæssigt skal dyrkes/fejres rituelt for at forhindre samfundet $\mathrm{i}$ at ende med bekrigende, despotiske individer (Durkheim 1912; Lundager Jensen 2005; Maryanski 2018).

Det bringer os til den anden hovedforklaring som drejer sig om symbolsk kompetence og ritualer. Udviklingen af symbolsk kompetence er kernen i de biokulturelle og biosemiotiske forskningspositioner. Vi er kulturmagere og kulturbrugere. Merlin Donald har argumenteret for at vi slet ikke kan bruge vores store hjerner uden kulturens stilladsering ("scaffold" - Donald 2001, 255). Kulturens kerne er imidlertid symbolsk tænkning. Vi er 'symbol-minded', dvs. symbolsk tænkende, som psykolog Judy S. DeLoache har vist i sine banebrydende studier af børns udvikling (DeLoache 2002;

17 "Assertion-anger, aversion-fear, disappointment-sadness, satisfaction-happiness" (Turner et al. 2018, 81; Turner 2000). 
2004; Pierroutsakos \& DeLoache 2003). Vi er desuden 'symbol-makers', dvs. symbolproducenter, som neuropsykolog Terrence Deacon har vist (Deacon 1997). Deacon har i flere studier vist at udviklingen af symbolsk kompetence er biologisk bestemt og har gjort det muligt for os at gribe ind i vores egen biologiske evolution (Deacon 2003, 93-95). Deacon argumenterer for at denne kompetence sandsynligvis er blevet udviklet ved hjælp af ritualer (Deacon 1997, 376ff.). Vi er som så mange andre arter præget af rituel adfærd, som er biologisk bestemt. Men med ekspansionen af følelseshjernen har vi været i stand til at eksternalisere og materialisere betydningsbærende og meningsfulde symboler som udtryk for gruppens og individernes identiteter. Turner og kolleger kalder i forlængelse af Durkheim disse symboler for totemer, som er genstand for religiøse ritualer (Turner et al. 2018, 111-113, 142-143). Symboler, ritualer og materielle genstande udgør en symbiose. Med andre ord kunne man sige, at medieringsprocesser har spillet en central rolle i vores biokulturelle evolution. Lige fra homo-arternes opståen har symboler, følelser og identitet været tæt vævet sammen. Gennem regelmæssige, religiøse ritualer bliver denne symbiose simuleret, genskabt og vedligeholdt. Arkæolog Mads Dengsø Jessen noterer sig desuden at overalt i verden organiseres ritualer omkring og inddrager den materielle verden som en forankring eller skabelon (Jessen 2012, 47). Religionsforsker Matthew Day argumenterer for at mennesket fylder verden med kulturelle artefakter netop for at komme ud over hjernens naturlige begrænsninger (Day 2004, 102). Vi kan dermed sige - med anknytning til medieteori - at symboler virkeliggøres gennem materielle medier og at sammenvavningerne af følelser, symboler og identitet fungerer via medier.

Under inspiration af neuropsykologisk forskning (især vedr. perception og hjernens forventningsdrift - 'predictive processing' - Geertz 2013) har Armin W. Geertz argumenteret for at vores nervesystem gør det muligt for os at påvirke hinandens interne processer, dvs. følelser og tanker, bl.a. gennem manipulation af den biologiske krop og brugen af sproglige og materielle medier. Det er sådan kulturens stillads virker. Ved at kommunikere med hinanden, ved at manipulere med kroppen gennem rituel dans, sang, sanse-manipulation eller brug af rusmidler er man i stand til at installere, overbevise, påtvinge og vedligeholde kulturelle normer og værdier i individerne (Geertz 2010; Jensen 2010, 2013, 2014).

Merlin Donald har vist hvordan udviklingen af hjernens cerebellum førte til større kontrol over kroppen. Han hævder at udviklingen af hjernebarken gjorde pandelappen i stand til at styre de motoriske hjerneområder. Det kalder han "cognitive governance", dvs. kognitiv styring af kroppen som førte til en vigtig revolution i artens evolution, nemlig den mimetiske revolution. Således blev mennesket i stand til at bruge kroppen som kommunikationsmiddel, som medie, på en meget nuanceret og effektiv måde (Donald 1991, 162ff.; 2002, 46ff.). For Donald er kulturelle systemer, som fx religion, kognitive styringsmekanismer: Religion er for Donald "a systemic cognitive consensus regarding the founding myths and rituals of social intercourse of a given society. Religions are governing institutions, and especially effective in the governance of ideas, practices, and beliefs" $(2019,159)$. 
Den mexicanske antropolog Roger Bartra har i sin velargumenterede bog Anthropology of the Brain (2014) fremført at hjernen består af fire dele: krybdyrhjernen, følelseshjernen, hjernebarken og 'exocerebrum' (eksohjernen eller den eksterne hjerne). Sidstnævnte skal forståes som at kultur fungerer som hjernens protese (Bartra 2014, $5,7)$. Det eksocerebrale netværk udgør et symbolsk substitutsystem (ibid., 43). Identitet ifølge Bartra er en samling symboler og kulturelle processer som trækker på etniske, sociale, religiøse, nationale, kønsmæssige osv. elementer til udviklingen af et 'jeg' (ibid., vii). Forskningens store udfordring er, mener Bartra, at finde ud af, hvordan nervesystemet er i stand til at arbejde med kulturens symboler, koder og signaler (ibid., 73) i sine bestræbelser på at kortlægge og fungere i et kulturelt miljø (ibid., 30). Bartra taler ikke om et system der er uafhængigt af kroppen eller består af metafysiske energier eller computerprogrammer (ibid., 5). Sociale og kulturelle netværk er tæt forbundet med hjernen på en måde der peger på mediebrug:

My hypothesis postulates that certain regions of the human brain genetically acquire a neurophysiological dependency on the symbolic substitution system. This system is obviously transmitted by cultural and social mechanisms. It is as if the brain needed the energy of outside circuits in order to synthesize and break down symbolic and imaginary substances in a particular anabolic and catabolic process. (Bartra 2014, 7)

Bartra citerer medieforskeren Marshall McLuhan som var overbevist om at massemediekommunikation som radio og TV er "massive extensions of our central nervous system" (McLuhan 1964, kap 31; citeret i Bartra 2014, 24). Bartra mener, at det langtfra er et moderne fænomen. Denne eksocerebrum fungerer fordi hjernens neurale netværk bruger de eksterne symbolske ressourcer, som om de er en udvidelse af de interne biologiske systemer, til processer som nervesystemet ikke kan klare uden (ibid., 26). Bartra argumenterer for at sprog, kunst, myter, kunstig hukommelse, matematik, symbolske systemer, litteratur, musik, dans, klassifikationssystemer og slægtskabssystemer er med til at 'oversætte' verden til hjernen. Sprog er det fornemste mekanisme; men sproget er ikke uafhængigt af symboler, ritualer, overbevisninger, mnemotekniske tegn og matematiske systemer, som deles af hele det sociale netværk (ibid., 32 \& 50). Lignende pointer ift. kommunikation og medier - men uden den neurobiologiske og kognitionsteoretiske forskning koblet på - fremsættes af Feldt og Høgel (Feldt 2019a; Feldt \& Høgel 2018a).

Udviklingen af den menneskelige bevidsthed foregår således ved hjælp af materielt og fysisk bårne symboler, dvs. i høj grad ved hjælp af genstande og redskaber, dvs. materielle medier. Man har i længere tid været opmærksom på redskabernes indvirkning på den menneskelige kognition. Ovenfor omtalte publikation af Spuhler og White (1959) sætter stenredskaberne centralt i den menneskelige evolution. I samme bog hævdede S.L. Washburn ligefrem at stenredskaberne bogstavelig talt har skabt Homo sapiens (Washburn 1959). Siden har man i samarbejde med neurologer konstateret hvor afgørende redskaberne har været i menneskets sociale udvikling, kommunikation- og sprogudvikling (Renfrew, Frith \& Malafouris 2008). Antropolog og bio$\log$ Andreas Roepstorff, der er leder af Interacting Minds Centre i Aarhus, påpeger at materielle symboler er bindeleddet mellem interne repræsentationer og eksterne ob- 
jekter og ord. Udviklingen af materielle symboler er en væsentlig årsag til vores udvidede kognition, som på engelsk hedder "extended cognition" (Roepstorff 2008, 2049). Arkæolog Lambros Malafouris argumenterer endvidere for at den tektonoetisk ${ }^{18}$ bevidsthed er den centrale evne i menneskets udvidede kognition (Malafouris 2008).

Arkæolog Miriam Noël Haidle har udviklet en analysemetode som påviser de komplekse kognitive processer som er på spil når man producerer redskaber (Haidle 2009, 2012; Lombard \& Haidle 2012). Stenredskabsproduktionen kræver planlægning, viden, en klar bevidsthed om tanke-og-handlings-processen samt evnen til at lære fra sig. Som Merlin Donald udtrykker det: Materiel kultur og den menneskelige kognition har udviklet sig i en symbiotisk evolution. Materiel kultur er en stabiliserende anker for megen menneskelig social kognition (Donald 1998, 181) og en vigtig del af gruppens og individets identitet (Bolus 2016).

Objekter har stor betydning for såvel ontogenesen som fylogenesen. Arkæolog Felix Riede og kolleger argumenterer for at en væsentlig del af Homo sapiens nichekonstruktion består i indlæring bl.a. gennem børns legetøj og andre redskaber. Denne praksis er en vigtig start på den læring som et barn skal have for at blive et fuldt kompetent menneske med mulighed for at skabe noget innovativt som voksen (Riede et al. 2018, 46). Børnenes forhold til dukker og legetøj hjælper barnet til at udforske, forstå og øve sig i sociale relationer, emotionelle tilstande, tilknytning, fantasi, symbolsk tænkning, hukommelse, empati og kulturelle værdier (se fx Fortuna et al. 2014; Jones et al. 2012; Kawin 2013; Litt 1986). Også dette indikerer at mediebrug har været afgørende for menneskets kognition og evolution.

Det viser sig at man kan spore den samme indvirkning af stenredskaber på andre homo-arter som Neandertalerne (Nowell 2016; Uthmeier 2016; Wynn \& Coolidge 2004; om Neandertalernes imponerende symbolske og kunstneriske kompetence se Hoffmann et al. 2018a; Hoffmann et al. 2018b; Rodríguez-Vidal et al. 2014; Zilhão et al. 2010 samt et tilsyneladende kultsted se Jaubert 2016) og at de tilmed omorganiserer abernes neurofysiologi (Fragaszy et al. 2013; Iriki \& Sakura 2008; Navarrete et al. 2015; jf. det banebrydende værk om dyr og redskaber Gibson \& Ingold 1998).

Arkæolog Dietrich Stout og neurolog Thierry Chaminade har udført interessante studier om stenredskaber, sprog og hjernen (Stout et al. 2008; Stout \& Chaminade 2012). Ved at scanne (FDG-PET og fMRI) hjernen under produktionen af henholdsvis Oldowan-redskaber (som er 2,6 millioner år gamle) og Late Acheulean-redskaber (som er resultat af en langt mere kompliceret proces der opstod for 700.000 år siden) demonstrerede de et funktionelt og anatomisk link mellem redskabsproduktion og sprog. Med andre ord hævder de at redskabsproduktion kunne have dannet vejen for udviklingen af sprog. Deres empiriske demonstration understøtter tidligere teorier (Greenfield 1991; Arbib 2005), dog ikke spejlneuronhypotesen som flere har anvendt

18 Fra græsk téktōn, 'tømrer', 'bygmester', og nous, 'forstand', 'sindelag'. Begrebet skal forstås som den materielle kulturs medierende rolle for såvel fylogenesen som ontogenesen i overgangen fra noesis til autonoesis, dvs. fra bevidsthed til erkendelse. Malafouris mener radikalt at et selv eller person ikke kan opstå (hverken i den ontogenetiske eller den fylogenetiske udvikling, dvs. som enkelt individ eller som art) uden en interaktion med den materielle verden (Malafouris 2008, 1998). 
til at forklare overgangen fra redskabsproduktion til sprog (Stout \& Chaminade 2012, 81-82). De gør sig til talsmænd for at teknologisk pædagogik, dvs. bevidst læring vha. materielle medier, dannede rammerne for evolutionen af mundtlig kommunikation (Stout \& Chaminade 2012, 82). Neurolog Scott H. Frey mener at redskabsproduktion og sprog har samme ophav (Frey 2008, 1955).

Vort forhold til genstande og redskaber er ikke kun instrumentelt og kognitivt. Vi tillægger genstande, objekter og redskaber betydning og knytter følelser til dem. Det kommer til udtryk i fx ens favoritsko eller -kasket, et barns dukke eller sutteklud, det hus og den by, man kommer fra, ens forlovelsesring osv. Disse kan have lige så stor betydning for individets udvikling og emotionelle tilstand som sociale relationer (Hinde 1998, 178; se Hinde \& Barden 1985 om teddybjørnens evolution - og kritikken af teorien - ved Morris, Reddy \& Bunting 1995). Når det drejer sig om religiøse objekter, steder og symboler bliver følelsestilstanden væsentlig forøget på godt og ondt. Dette fører os tilbage til følelsers betydning for menneskets udvikling som ovenfor beskrevet ift. de første jæger-samler-grupperinger. Det er derfor nødvendigt, som vi har forsøgt at pege på her, at teoretisere medier og medialitet i et langt og bredt religionsvidenskabeligt perspektiv, samt i en evolutions- og kognitionsteoretisk sammenhæng, eftersom udviklingen af en mere udvidet og avanceret følelsespalet i vores vurdering efter al sandsynlighed hænger sammen med mediebrug.

\section{Materialitet, symboler og medier}

Ovennævnte forskningserkendelser bringer os således tilbage til medier. I og med at vi er følelsesladede, ritualfikserede væsner, med en veludviklet symbolsk kompetence samt evnen til at materialisere symbolerne, er vi væsener som er totalt afhængige af socialitet og kultur for at bruge vores store hjerner og for at forstå os selv og hinanden. Samtidigt får medier hermed sin rette plads i diskussionen. For kan man forestille sig symbolsk kompetente væsener uden kommunikation? Og kan man forestille sig kommunikation uden anvendelse af materielle medier? Nej.

Homo-arten har omdannet verden til betydningsmættede, følelsesbetonede, symbolske fællesskaber. Stort set alt kan bruges som symboler til at kommunikere med og påvirke andre mennesker på godt og ondt. I oversigten herunder forsøger vi at give et overblik over de processer, mekanismer og medier der interagerer i den menneskelige kommunikation med særligt fokus på udpegning af felter af religionsvidenskabelig relevans. 
Mekanismer og processer der påvirker religion som kulturproduktion

1. Neurobiologiske forhold: neurologiske og kropslige processer, bevidsthed, hukommelse, selvfornemmelse, emotioner og kognitive kort

2. Psykologiske forhold: følelser, personlighed, drømme, mv. (i samspil med sproglige udtryk)

3. Socialiseringsforhold: omsorgsrelationer, sprog og kommunikation, selvbiografier

4. Formaliserede institutioner: symbolske systemer, univers-vedligeholdelsesteknikker og -institutioner; magt- og diskurslinjer; habitus og kulturel kapital

5. Større sociale og kulturelle selektionsmekanismer: samfundsudvikling, katastrofer, stagnation eller krig

Materielle medier for religiøs kommunikation

1. Kroppens mimetiske virkemidler: dans, gestik, holdning, bevægelse, musik

2. Stemmen: basale, emotionelle lyde, sang og mundtlige overleveringer

3. Symbolsk materialitet: barkruller, pindebundter, palmeblade, helleristninger og perler

4. Ikonografi (kroppen): kropsudsmykning og dragter, smykker, rituel og anden symbolsk adfærd

Ikonografi (genstande): naturlige genstande som bestemte træer, sten, buske, planter; og menneskeskabte genstande som statuer, dukker og masker

Ikonografi (arkitektur og rum): templer, huse, søjler og pæle; "natur"-rum såsom skovlysninger, haver, bjergtoppe, vildmarker, søer, kilder, huler

Ikonografi (billeder): kunst, fotografier, tegneserier

6. Skriftsprogsmedier: bøger, ruller, tavler, breve og papyri, email

7. Audiovisuelle medier: film, $\mathrm{tv}$, video, telefon, digitale spil, internet

Religiøse kommunikationsgenrer

1. Formelle fortællende genrer: myter, legender, sange, eper, sagaer, hagiografier, noveller, romaner, visse skuespil

2. Personlige genrer: taler, rejseberetninger, omvendelsesberetninger, selvfortællinger, drømmeberetninger, visionsberetninger, dagbøger, vejledning, vittigheder og breve, visse ordsprog og gåder

3. Rituelle tekster: hymner, mantraer, homilier, litanier, magiske formler, orakler, tungetale og bønner, visse skuespil, prædikener

4. Traditionsoverleveringsgenrer/teologisk selvrefleksive genrer: eksegetiske kommentarer, apologetik, visdomslitteratur, love, kodekser, dekreter og didaktiske formler (visse ordsprog, gåder, epigrammer).

5. Håndbøger: magiske bøger, ritualhåndbøger, meditationshåndbøger, bønnebøger, selvhjælpslitteratur osv. 
Tabel 1. Religiøs kommunikation og medier. (Redigeret og let forandret udgave af tabel i Geertz 2008b, 29). I forbindelse med materielle medier er det værd at understrege, at multimedialitet - den samtidige anvendelse af flere forskellige medier og/eller remediering - $\mathrm{fx}$ af samme narrativ - i forskellige medier altid har fundet sted, og ikke er et rent samtidsfænomen, samt at kropslige-affektive effekter og påvirkninger i mange tilfælde er vigtigere end kommunikation af religiøst indhold. ${ }^{19}$

Ovenstående skema muliggør og letter efter vores mening det bredere komparative arbejde, som er religionsvidenskabens interesse, og hvis biokulturelle forudsætninger vi har skitseret ovenfor. På den baggrund kan vi vende tilbage til Armin W. Geertz' religionsdefinition fra 1990erne $(1999,471)$ ifl. hvilken religion forstås som former for kulturel betydningsdannelse ${ }^{20}$ og social institutions-formation som fremmer ideale fortolkninger af livet og ideal praksis med reference til postulerede transempiriske magter eller væsener (vores oversættelse). Dette er en formulering af en forståelse af religion som man på flere måder kan kalde klassisk og som mange religionsforskere formodentlig vil nikke genkendende til. ${ }^{21}$ Den muliggør komparation og diskussion i sin opdeling af religion i to grundfænomener: kommunikation og handling. Her vil vi pege på, at ovenstående skema tydeliggør at et mediebegreb kan forene de to basale kategorier, som Geertz' 1990er religionsdefinition var baseret på, nemlig en distinktion mellem en kommunikationstypologi og en handlingstypologi (Geertz 1999) - et træk der er ganske typisk i mange religionsforståelser - på måder der gør det muligt at tage det biokulturelle perspektiv alvorligt. Derfor bør der, mener vi, lægges en medietypologi til kommunikations- og handlingstypologien i fremtidige diskussioner, ligesom de biokulturelle og kognitive forudsætninger også bør inddrages. En genretypologi - som ovenfor vist - mener vi tillige kan være nyttig i komparativt

19 Vi vil ikke her gå ind i al litteraturen vedr. disse under-felter, men blot henvise til enkelte publikationer der kan bringe læseren videre inden for visse områder: vedr. tekst som materialitet, se tidsskrifterne Material Religion samt Postscripts - the Journal of Sacred Texts and Contemporary Worlds, vedr. kunst: Kandel 2016; C. Geertz 1976; Hackett 1996; særligt vedr. hulemalerier, se Petzinger 2016; dans: se Hanna 1979; musik: Brown \& Volgsten 2006; Partridge 2004-2006; hellige områder, geografi, rum: Carrasco 1990; Carver 1993; Feldt 2012; tøj/kostumer: Arthur 1999; Gilhus 2019; Biebuyck \& Van Den Abbeele 1984; masker: Pernet 1992; Edson 2005; dukker/automata: Boehen 1929; Dautenhahn 2007; Kang 2011; Krause et al. 2011; Nelson 2001; Reilly 2011; Richardson 2016; Truit 2015; Voskuhl 2013; Wang et al. 2015; Wood 2002; redskaber: Lienard \& Sørensen 2013; processioner: se RvTs temanummer herom (bd. 66, 2017). Dette er blot et meget lille udpluk af relevant litteratur; meget andet kunne også være nævnt, fx om statuer, altre, religiøst nips, smykker, o.a.

$20 \mathrm{Vi}$ erstatter her ordet 'system' med den mere forsigtige term 'betydningsdannelse', da nyere forskning problematiserer et religionsbegreb der fokuserer for snævert på det systematiske aspekt i religionsdefinitioner (jf. Feldt 2016b og Gilhus og Mikaelssons forståelse af religion som et flydende kulturfelt).

21 Om end den ved sin udgivelse afstedkom en omfattende og interessant diskussion i dansk religionsvidenskab (Bilde 1991 og 1997; Geertz 1996 og 1997a; Schjødt 2004; Hammersholt \& Schaffalitzky de Muckadell 2011; se også Gasparro 2016 for en reaktion mod Geertz 1997b). I et særnummer af institutbladet Tabu, redigeret af Linda Langemark, findes en række interessante interviews med ansatte på Afdeling for Religionshistorie, Københavns Universitet vedrørende deres reaktioner til Bilde-Geertz debatten og til religionsdefinitioner i almindelighed (Langemark 2007). 
øjemed, i det vi jo, varierende fra kontekst til kontekst, religion til religion, ser forskellige typer af medier og genrer, der tilskrives en særlig autoritet, relevans, mening eller evne til at gøre de overnaturlige væsener præsente og oplevelsesbare. ${ }^{22}$

\section{Konklusion}

Medier, bevidsthed, kultur og religion har altid haft et symbiotisk forhold. Det nye i dag er ikke mindst omfanget af medieformer samt visse strukturelle og teknologiske forandringer. Merlin Donald er kendt for sin hypotese om at homo-arten har været igennem tre afgørende kognitive overgange - eller revolutioner om man vil - som alle er medierelaterede, nemlig den mimetiske (overgangen mellem australopithecinerne til homo-linjen), den mytiske (den anatomisk moderne Homo sapiens) og den teoretiske (for ca. 40.000 år siden med udviklingen af symbolteknologien). Den mimetiske revolution gav mere præcis og selvbevidst kontrol over mimikken. Den mytiske revolution medførte en betydelig rigere og hurtigere akkumulation af kulturel viden gennem tale. Den teoretiske revolution medførte en meget mere kraftig og abstrakt kultur gennem udviklingen af symbolteknologien (tegn, billedkunst, kunsthåndværk, skrift og i dag med computerteknologien) - (Donald 2011, 72-73). Donald har for nyligt argumenteret for at med den voldsomme teknologiske udvikling i samtiden ser det ud til at vi er ved at nå frem til en fjerde revolution:

It is based on a significant shift in the structure of the cognitive-cultural system: Human external memory banks are evolving into active sources of mental representations, rather than passive ones, as they had been until the very recent past. Potentially, they are changing the nature of the social-cognitive dynamic upon which human society has developed its institutions and ideas in the past. This shift is still in its early stages, but given the potential for very rapid technological change, it could have very major implications for how we perform our cognitive business in the future. It could also change who we are, and what we aspire to become. (Donald 2019, 159).

Donald peger her på, at eksterne hukommelseslagre i samtiden er ved at udvikle sig til aktive kilder til mentale repræsentationer, snarere end de passive vi hidtil har været vant til, og at det kan ændre de socialt-kognitive dynamikker. Uden at Donald konkret udpeger hvad ændringerne vil bestå i, så flugter hans pointe om at mediemæssig og teknologisk udvikling medfører sociale og kognitive forandringer med den tilgang som klassiske medieforskere som Marshall McLuhan (1994) og dennes elev, Joshua Meyrowitz (1986; 1994; 2001), har stået for. Hertil kan vi føje at medieteknologier i samtiden også er blevet lettere og hurtigere at bruge, og samtidigt billigere og mere udbredte til flere samfundslag. Det kan betyde - og her kan vi knytte an til teorierne vedr. udviklingen i feltet medialisering, religion og internet i samtiden - at den eksterne, materielle verden kan blive kognitivt sværere at skelne fra den symbolsk-materielle verden (cf. Plate 2017, ix) i takt med udviklingen i den digitale, visu- 
elle og cinematiske teknologi. Den teknologiske udvikling, hvor film-, tv- og spil-produktion trækker på æstetiske ${ }^{23}$ teknikker fra religionerne og i stadig højere grad skaber meningsfulde totaliteter, ${ }^{24}$ den stadigt mere omfattende påvirkning fra film, medier og tv på religiøse praksisser i samtiden (Plate 2017, 4-5), og vekselvirkningen mellem verden 'derude' og den genskabte verden på skærmen, medfører ofte at skellet mellem de to opleves som mindre og/eller som udvisket (Plate 2017,3). Dette kan potentielt føre til mere 'religionificering' af samfundet, snarere end mindre. ${ }^{25}$

Hvad end fremtiden bringer, så har vores hovedanliggende her været at pege på, at medier og mediebrug har gjort en forskel for religioner og religiøse forandringer i den lange og brede religionshistorie, og at foreslå at religionsvidenskab samt kognitions- og evolutionsstudier tager et bredt mediebegreb op og inkluderer mediemodeller og -terminologi i nye analysestrategier. Udviklingen i feltet viser også at ikke alene religionsvidenskab og kognitions- samt evolutionsstudier, men også medievidenskab, i takt med disse forandringer har bevæget sig - og i samtiden bevæger sig yderligere - væk fra studier af tekst og kognition isoleret fra krop, rum, materialitet, medier og netværk. Disse områder, dvs. både mediestudier, religionsstudier og kognitions- og evolutionsstudier, bevæger sig henimod inddragelse af bredere kontekster, hvor man ikke tilgår hverken det enkelte medie, hjernen, eller en singulær tekst isoleret, men i interaktion med materialitet, krop, rum, teknologi, socialitet, kultur og historiske forandringer. Som vi håber at have vist, kan religionsvidenskabelige kognitions- og evolutions-studier med fordel inddrage mediebegrebet i langt højere grad end tidligere, ligesom religionsvidenskabelige mediestudier - som vi har forsøgt at argumentere for - bør bredes ud så den inkluderer den lange og brede religionshistorie. På samme måde vil det styrke fremtidige religionsvidenskabelige medie-analyser at bevæge sig hinsides undersøgelser af religiøs kommunikation i moderne massemedier, hvor selve mediet anskues som tekst og religion som et spørgsmål om repræsentationer, og henimod en mere omfattende inklusion af materialitet, krop, hjerne og netværk og ikke mindst medie-specifikke modeller.

\section{LITTERATUR}

Ahlin, Lars

2008 “The Meaning of 'Spirituality': A Discussion with Its Starting Point in an Investigation among Alternative Therapists", Implicit Religion 1, 25-38. https://doi.org/10.1558/imre.v11i1.25

Andersen, Casper, Alexandra R. Kratschmer, Mathias Clasen \& Trine Kellberg Nielsen

2019 “Indledning: Mennesket i biokulturelt perspektiv", in Trine Kellberg Nielsen, Casper Andersen,

23 Æstetik forstås her i den græske betydning (aisthesis, sansning), jf. Grieser og Johnston 2017.

24 Hermed menes fremstillingen af hele, mere altomsluttende, gennemtænkte alternative verdener, snarere end brugen af sammenblandede 'ready-mades'.

25 Dette er Ingvild S. Gilhus' term (Gilhus 2019), jf. Gilhus' pointer i artiklen vedr. medier i Norge i samtiden, hvor printmedier suppleres af andre medietyper, der favoriserer billeder, film og korte følelsesmæssigt engagerende fortællinger, hvor fokus er på 'showing and telling, rather than on preaching and teaching', og hvor disse medieprocesser til sammen har været med til at udvide opfattelsen af, hvad der er legitim religiøs autoritet. 
Alexandra R. Kratschmer \& Mathias Clasen, eds., Menneske, kultur, evolution - et biokulturelt perspektiv, Aarhus: Aarhus Universitetsforlag, 11-31.

Arbib, Michael A.

2005 "From Monkey-Like Action Recognition to Human Language: An Evolutionary Framework for Neurolinguistics", Brain and Behavioral Sciences 28, 105-124. https://doi.org/10.1017/S0140525X05000038

Arthur, Linda B., ed.

1999 Religion, Dress and the Body, Oxford \& New York: Berg. https://doi.org/10.2752/9781847888839

Bartra, Roger

2014 Anthropology of the Brain: Consciousness, Culture, and Free Will, overs. af Gusti Gould. Cambridge: Cambridge University Press. https://doi.org/10.1017/CBO9781107446878

Baunvig, Katrine Frøkjær

2017 "Kirkehistorisk adaption: om Grundtvig, (Grundtvigs) Luther og kulturel evolution", in Ove Korsgaard \& Michael Schelde, eds., På afstand: forskydninger mellem Grundtvig og Luther, Frederiksberg: Eksistensen Akademisk, 195-212.

Bellah, Robert N.

2011 Religion in Human Evolution: From the Paleolithic to the Axial Age, Cambridge \& London: Harvard University Press. https://doi.org/10.4159/harvard.9780674063099

Biebuyck, Daniel \& Nelly Van Den Abbeele

1984 The Power of Headdresses: A Cross-Cultural Study of Forms and Functions, Brussels: Tendi.

Bilde, Per

1991 "Begrebet religion. Et indlæg i debatten om religionsvidenskabens objekt drøftet i lyset af beslægtede begreber", Chaos. Dansk-norsk tidsskrift for religionshistoriske studier 15, 4-24.

1997 "Er 'religion' et autonomt forskningsfelt? Et svar til Armin W. Geertz", Chaos. Dansk-norsk tidsskrift for religionshistoriske studier 27, 119-127.

Boehn, Max Von

1929 Puppen und Puppenspiele, München: F. Bruckmann, overs. til Puppets and Automata af Josephine Nicoll. New York: Dover Publications, Inc., 1972.

Bolus, Michael

2016 "Tracing Group Identity in Early Upper Paleolithic Stone and Organic Tools - Some Thoughts and Many Questions", in Miriam N. Haidle, Nicholas J. Conard \& Michael Bolus, eds., The Nature of Culture: Based on an Interdisciplinary Symposium 'The Nature of Culture', Tübingen, Germany, Dordrecht: Springer Verlag, 79-85. https://doi.org/10.1007/978-94-017-7426-0_8

Boyd, Robert \& Peter J. Richerson

1985 Culture and the Evolutionary Process, Chicago: University of Chicago Press.

Brown, Steven and Ulrik Volgsten, eds.

2006 Music and Manipulation: On the Social Uses and Social Control of Music, New York \& Oxford: Berghahn Books.

Campbell, Heidi \& Gregory P. Grieve, eds.

2014 Playing with Religion in Digital Games, Indiana University Press.

Carrasco, Davíd

1990 Religions of Mesoamerica: Cosmovision and Ceremonial Centers, San Francisco: Harper.

Carver, M. O. H.

1993 Arguments in Stone: Archaeological Research and the European Town in the First Millennium, Oxford: Oxbow Books.

Cavalli-Sforza, Luigi Luca 
2000 Genes, Peoples and Languages, oversat af Mark Seielstad. London: Penguin Books Ltd., 2000.

Cavalli-Sforza, Luigi Luca \& M. W. Feldman

1981 Cultural Transmission and Evolution, Princeton: Princeton University Press.

Clark, Lynn Schofield

2003 From Angels to Aliens: Teenagers, the Media, and the Supernatural, Oxford: Oxford University Press.

Cowan, Douglas E.

2011 "Internet", in M. Stausberg \& S. Engler, eds., The Routledge Handbook of Research Methods in the Study of Religion, London: Routledge, 459-473.

Dautenhahn, Kerstin

2007 "Socially Intelligent Robots: Dimensions of Human-Robot Interaction", Philosophical Transactions of the Royal Society B 362, 679-704. https://doi.org/10.1098/rstb.2006.2004

Davidsen, Markus

2013 "Fiction-based Religion: Conceptualising a New Category against History-based Religion and Fandom", Culture and Religion: An Interdisciplinary Journal 14/4, 378-395. https://doi.org/10.1080/14755610.2013.838798

2018 "Introduction", in Markus Davidsen, ed., Narrative and Belief: The Religious Affordance of Supernatural Fiction, London: Routledge. https://doi.org/10.4324/9780203712344

Dawson, Lorne L.

2004 "Religion and the Quest for Virtual Community", in L.L. Dawson \& D.E. Cowan, eds., Religion Online: Finding Faith on the Internet, London: Routledge, 75-89.

Dawson, Lorne \& Douglas Cowan

2004 "Introduction", in L.L. Dawson \& D.E. Cowan, eds., Religion Online: Finding Faith on the Internet, London: Routledge, 1-16.

Day, Matthew

2004 "Religion, Off-Line Cognition and the Extended Mind", Journal of Cognition and Culture 4/1, 101121. https://doi.org/10.1163/156853704323074778

de Certeau, Michel

1984 The Practice of Everyday Life, Berkeley: University of California Press.

Deacon, Terrence W.

1997 The Symbolic Species: The Co-Evolution of Language and the Human Brain, London: Allen Lane The Penguin Press.

2003 "Multilevel Selection in a Complex Adaptive System: The Problem of Language Origins", in: Bruce H. Weber \& David J. Depew, eds., Evolution and Learning: The Baldwin Effect Reconsidered, Cambridge \& London: The MIT Press, 81-106.

Debray, Regis

1996 Media Manifestos: On the Technological Transmission of Cultural Forms, New York: Verso.

Dehaene, Stanislas

2009 Reading in the Brain: The Science and Evolution of a Human Invention, New York: Viking.

Dehaene, Stanislas, et al.

2010 "How Learning to Read Changes the Cortical Networks for Vision and Language", Sciencexpress 1-12, 11-28. https://doi.org/10.1126/science.1194140

DeLoache, Judy S.

2002 “The Symbol-Mindedness of Young Children”, in Willard W. Hartrup \& Richard A. Weinberg, eds., Child Psychology in Retrospect and Prospect: In Celebration of the 75th Anniversary of the Institute of Child Development. The Minnesota Symposia on Child Psychology, Mahwah \& London: Lawrence Erlbaum Associates, Publishing, vol 32, 73-101. 
https://doi.org/10.4324/9781410613141-3

2004 "Becoming Symbol-Minded", TRENDS in Cognitive Sciences 8/2, 66-70. https://doi.org/10.1016/j.tics.2003.12.004

Donald, Merlin

1991 Origins of the Modern Mind: Three Stages in the Evolution of Culture and Cognition, Cambridge \& London: Harvard University Press.

1998 "Material Culture and Cognition: Concluding Thoughts", in Colin Renfrew \& Chris Scarre, eds., Cognition and Material Culture: The Archaeology of Symbolic Storage, Oxford: Oxbow Books \& Cambridge: University of Cambridge, 181-187.

2001 A Mind So Rare: The Evolution of Human Consciousness, New York \& London: W. W. Norton \& Company.

2011 "The First Hybrid Minds on Earth", in A.W. Geertz \& J.S. Jensen, eds., Religious Narrative, Cognition and Culture: Image and Word in the Mind of Narrative, Sheffield \& Oakville: Equinox Publishing, Ltd., 67-96.

2019 "Self-Programming and the Self-Domestication of the Human Species: Are We Approaching a Fourth Transition?" in A.K. Petersen, I.S. Gilhus, L.H. Martin, J.S. Jensen \& J. Sørensen, eds., Evolution, Cognition, and the History of Religion: A New Synthesis, Leiden: Brill, 159-174. https://doi.org/10.1163/9789004385375_011

Durkheim, Émile

1912 Les formes élémentaires de la vie religieuse: Le système totémique en Australie, Paris: Presses Universitaires de France.

Edson, Gary

2005 Masks and Masking: Faces of Tradition and Belief Worldwide, Jefferson, North Carolina \& London: McFarland \& Company, Inc., Publishers.

Feldt, Laura

2009 "Fantasizing the Fall. Reception and transformation of Genesis 3 in Philip Pullman's Fantasy Trilogy His Dark Materials", in K. Nielsen, ed., Receptions and Transformations of the Bible in Literature, Aarhus: Aarhus Universitetsforlag, 48-64.

2016 "Contemporary Fantasy Fiction and Representations of Religion: Playing with Reality, Myth and Magic in His Dark Materials and Harry Potter", Religion 46/4, 550-574. https://doi.org/10.1080/0048721X.2016.1212526

2019 "Marginality, Media and Mutations of Religious Authority in the History of Christianity" (Introducing the concepts), in Laura Feldt \& Jan N. Bremmer, eds. Marginality, Media and Mutations of Religious Authority in the History of Christianity, Leuven: Peeters, 1-21.

Feldt, Laura, ed.

2012 Wilderness in Mythology and Religion: Approaching Religious Spatialities, Cosmologies and Ideas of Wild Nature, Berlin: Walter de Gruyter. https://doi.org/10.1515/9781614511724

Feldt, Laura \& Jan N. Bremmer, eds.

2019 Marginality, Media and Mutations of Religious Authority in the History of Christianity, Studies in the History and Anthropology of Religion 6, Leuven: Peeters.

Feldt, Laura \& Christian Høgel, eds.

2018 Reframing Authority: The Role of Media and Materiality, London: Equinox.

Forbes, Bruce D. \& Jeffrey H. Mahan

2005 Religion and Popular Culture in America, Los Angeles: University of California Press.

Fortuna, Keren, Liora Baor, Salomon Israel, Adi Abadi \& Ariel Knafo

2014 "Attachment to Inanimate Objects and Early Childcare: A Twin Study", Frontiers in Psychology 5, article 486, 1-7. https://doi.org/10.3389/fpsyg.2014.00486 
Fragaszy D.M., D. Biro, Y. Eshchar, T. Humle, P. Izar, B. Resende \& E. Visalberghi E.

2013 "The Fourth Dimension of Tool Use: Temporally Enduring Artefacts Aid Primates Learning to Use Tools", Philosophical Transactions of the Royal Society B 368: 20120410. https://doi.org/10.1098/rstb.2012.0410

Frey, Scott H.

2008 "Tool Use, Communicative Gesture and Cerebral Asymmetries in the Modern Human Brain", Philosophical Transactions of the Royal Society B. Biological Sciences 363, 1951-1957. https://doi.org/10.1098/rstb.2008.0008

Gasparro, Giulia Sfameni

2016 “A Method without Explanatory Theory: Ugo Bianchi's Historical- Comparative Methodology after Thirty Years", in Peter Antes, Armin W. Geertz, and Mikael Rothstein, eds., Contemporary Views on Comparative Religion in Celebration of Tim Jensen's 65th Birthday, Sheffield and Bristol, CT: Equinox Publishing Ltd., 73-86.

Geertz, Armin W.

1987 Hopi Indian Altar Iconography, Leiden: E. J. Brill.

1996 "Begrebet religion endnu engang: Et deduktivt forsøg", Chaos. Dansk-norsk tidsskrift for religionshistoriske studier 26, 109-128.

1997a "Illumination, korrespondens og religion. Et svar til Per Bilde", Chaos. Dansk-norsk tidsskrift for religionshistoriske studier 28, 145-155.

1997b “Theory, Definition, and Typology: Reflections on Generalities and Unrepresentative Realism", Temenos. Studies in Comparative Religion Presented by Scholars in Denmark, Finland, Norway and Sweden 33, 29-47. https://doi.org/10.33356/temenos.4905

1999 "Definition as Analytical Strategy in the Study of Religion", Historical Reflections/Reflections Historiques 25/3, 445-475.

2008a “Religion og kognition - En introduktion", Religion: Tidsskrift for Religionslærerforeningen for Gymnasiet og HF, september 2008 (3), 15-27.

2008b “Religiøs narrativitet - Et definitionsforsøg”, in Jeppe Sinding Jensen \& Armin W. Geertz, eds., Religiøs narrativitet, kognition og kultur, Højbjerg: Forlaget Univers, 26-45.

2010 "Brain, Body and Culture: A Biocultural Theory of Religion", Method and Theory in the Study of Religion 22/4, 304-321. https://doi.org/10.1163/157006810X531094

2013 "Whence Religion? How the Brain Constructs the World and What This Might Tell Us about the Origins of Religion, Cognition and Culture", in Armin W. Geertz, eds., Origins of Religion, Cognition and Culture, Durham: Acumen Publishing Limited, 17-70. https://doi.org/10.4324/9781315728988

2015 "Evolution of Religious Belief", International Encyclopedia of the Social E Behavioral Sciences, 2nd edition. Oxford: Elsevier, 20, 384-395. https://doi.org/10.1016/B978-0-08-097086-8.81055-7

2017 "Religious Bodies, Minds and Places. A Cognitive Science of Religion Perspective", in Laura Carnevale, ed., Spazi e luoghi sacri espressioni ed esperienze di vissuto religioso, Bari: Edipuglia, 3552.

2018 "Hvorfor, hvorfra (og hvornår) kom religion?" Religionsvidenskabeligt Tidsskrift 67, 111-137. https://doi.org/10.7146/rt.v0i0.104022

Geertz, Clifford

1976 “Art as a Cultural System”, Modern Language Notes 91/6, 1473-1499. Genoptrykt i Clifford Geertz, Local Knowledge: Further Essays in Interpretive Anthropology, New York: Basic Books 1983, 94-120.

Gibson, James J.

1950 The Perception of the Visual World, Boston: Houghton Mifflin.

1966 The Sense Considered as Perceptual Systems, Boston: Houghton Mifflin. 
1979 The Ecological Approach to Visual Perception, Boston: Houghton Mifflin.

Gibson, Kathleen R. \& Tim Ingold, eds.

1993 Tools, Language and Cognition in Human Evolution, Cambridge: Cambridge University Press.

Gilhus, Ingvild Sælid

2019a "Enclothed Cognition and Ancient Monasticism", in Anders Klostergaard Petersen, Ingvild Sælid Gilhus, Luther H. Martin, Jeppe Sinding Jensen \& Jesper Sørensen, eds., Evolution, Cognition, and the History of Religions: A New Synthesis, Leiden and Boston: Brill, 547-561.

2019b "Mutations of Religious Authority in Contemporary Norway - Marginality and Mediatization in the Case of the Man from Snåsa", in L. Feldt \& J. N. Bremmer, eds., Marginality, Media and Mutations of Religious Authority in the History of Christianity, Leuven: Peeters, 193-208.

Goody, Jack

1987 The Interface between the Written and the Oral, Cambridge: Cambridge University Press.

Greenfield, Patricia M.

1991 "Language, Tools, and Brain: The Development and Evolution of Hierarchically Organized Sequential Behavior", Behavioral and Brain Sciences 14, 531-595. https://doi.org/10.1017/S0140525X00071235

Grodal, Torben

2009 Embodied Visions: Evolution, Emotion, Culture, and Film, Oxford: Oxford University Press. https://doi.org/10.1093/acprof:oso/9780195371314.001.0001

Hackett, Rosalind I. J.

1996 Art and Religion in Africa, London \& New York: Cassell.

Hadden, Jeffrey K. \& Douglas E. Cowan, eds.

2000 Religion on the Internet: Research Prospects and Promises, Amsterdam: JAI.

Haidle, Miriam Noël

2009 "How to Think a Simple Spear", in Sophie A. de Beaune, Frederick L. Coolidge \& Thomas Wynn, eds., Cognitive Archaeology and Human Evolution, Cambridge: Cambridge University Press, 57-73.

2012 How to Think Tools? A Comparison of Cognitive Aspects in Tool Behavior of Animals and During Human Evolution, Tübingen: Eberhard Karls Universität Tübingen.

Hammersholt, Torben and Caroline Schaffalitzky de Muckadell, eds.

2011 At kortlægge religion: Grundlagsdiskussioner i religionsforskningen, Højbjerg: Forlaget Univers.

Hanna, Judith Lynne

1979 To Dance Is Human: A Theory of Nonverbal Communication, Chicago and London: The University of Chicago Press.

Heelas, Paul \& Linda Woodhead

2004 The Spiritual Revolution. Why Religion Is Giving Way to Spirituality, New York: Wiley.

Heider, F.

1959 "Thing and Medium", Psychological Issues 1, 1-34.

Helland, Christopher

2005 “Online Religion as Lived Religion: Methodological Issues in the Study of Religious Participation on the Internet", In Online-Heidelberg Journal of Religions on the Internet vol.1.1. Available at: http://archiv.ub.uni-heidelberg.de/volltextserver/5823/

Hinde, Robert A.

1998 "Mind and Artefact: a Dialectical Perspective", in Colin Renfrew \& Chris Scarre, eds., Cognition and Material Culture: the Archaeology of Symbolic Storage, Oxford: Oxbow Books \& Cambridge: University of Cambridge, 175-179. 
Hinde, Robert A. \& L. Barden

1985 "The Evolution of the Teddy Bear", Animal Behaviour 33/4, 1371-1373. https://doi.org/10.1016/S0003-3472(85)80205-0

Hjarvard, Stig

2008a "Introduction: The Mediatization of Religion: Enchantment, Media and Popular Culture", Nordic Journal of Media Studies 6, 3-8. https://doi.org/10.1386/nl.6.1.3_2

2008b En verden af medier: Medialiseringen af politik, sprog, religion og leg, Frederiksberg: Samfundslitteratur.

2011 "The Mediatisation of Religion: Theorising Religion, Media and Social Change", Culture and Religion, 12/2, 119-135. https://doi.org/10.1080/14755610.2011.579719

2012 “Three Forms of Mediatized Religion”, in M. Lövheim \& S. Hjarvard, eds., Mediatization and Religion: Nordic Perspectives, Gothenburg: Nordicom, 21-44.

Hjarvard, Stig \& Mia Lövheim, eds.

2012 Mediatization and Religion: Nordic Perspectives, Göteborg: Nordicom.

Hoffmann, Dirk L., Diego E. Angelucci, Valentin Villaverde, Josefina Zapata \& João Zilhão

2018a "Symbolic Use of Marine Shells and Mineral Pigments by Iberian Neandertals 115,000 Years Ago", Science Advances 4, no. eaar5255, 1-6. https://doi.org/10.1126/sciadv.aar5255

2018b "U-Th Dating of Carbonate Crusts Reveals Neandertal Origin of Iberian Cave Art", Science 359, 912-915. https://doi.org/10.1126/science.aap7778

Hoover, Stewart, ed.

2016a Religious Authority in the Media Age, State Park: Pennsylvania State University Press.

2016b The Media and Religious Authority, State Park, Pennsylvania: Pennsylvania State University Press. Horsfield, Peter

2015 From Jesus to the Internet. A History of Christianity and Media, London: Wiley.

Hunt, Terry \& Carl Lipo

2011 The Statues That Walked: Unraveling the Mystery of Easter Island, New York: Free Press.

Højsgaard, Morten T. \& Margit Warburg, eds.

2005 Religion and Cyberspace, London \& New York: Routledge. https://doi.org/10.4324/9780203003572

Iriki, Atsushi \& Osamu Sakura

2008 "The Neuroscience of Primate Intellectual Evolution: Natural Selection and Passive and Intentional Niche Construction", Philosophical Transactions of the Royal Society B 363, 2229-2241. https://doi.org/10.1098/rstb.2008.2274

Jaubert, Jacques et al.

2016 "Early Neandertal Constructions Deep in the Bruniquel Cave in Southwestern France", Nature 534, 111-115. https://doi.org/10.1038/nature18291

Jessen, Mads Dengsø

2012 "Material Culture, Embodiment and the Construction of Religious Knowledge", in Marie Louise Stig Sørensen \& Katharina Rebay-Salisbury, eds., Embodied Knowledge: Perspectives on Belief and Technology, Oxford and Oakville: Oxbow Books and The David Brown Books Company, 40-51. https://doi.org/10.2307/j.ctvh1dx2t.7

Johansen, Kirstine Helboe \& Katrine Frøkjær Baunvig

2014 "Gudstjeneste og erkendelse: En Donaldsk analyse af kirkens gudstjenester og deres deltagere", Dansk Teologisk Tidsskrift 77/4, 297-316. https://doi.org/10.7146/dtt.v77i4.105727

Jones, Liz, Maggie MacLure, Rachel Holmes \& Christina MacRae

2012 "Children and Objects: Affection and Infection", Early Years. An International Research Journal 32/1, 49-60. https://doi.org/10.1080/09575146.2011.593029 
Kandel, Eric R.

2016 Reductionism in Art and Brain Science, New York: Columbia University Press. https://doi.org/10.7312/kand17962

Kang, Minsoo

2011 Sublime Dreams of Living Machines: The Automaton in the European Imagination, Cambridge \& London: Harvard University Press.

Kawin, Ethel

2013 "The Function of Toys in Relation to Child Development", Childhood Education 11/3, 122-132. https://doi.org/10.1080/00094056.1934.10725325

Kelso, Sylvia

2007 "The God in the Pentagram: Religion and Spirituality in Modern Fantasy", Journal of the Fantastic in the Arts 18, 61-82.

Krause, Jens, Alan F. T. Winfield \& Jean-Louis Deneubourg

2011 "Interactive Robots in Experimental Biology", Trends in Ecology and Evolution 26/7, 369-375. https://doi.org/10.1016/j.tree.2011.03.015

Langemark, Linda

2007 Tema om religionsdefinitioner og religionsvidenskabelig praksis, Tabu, maj 2007, København: Afdeling for Religionshistorie, Institut for Tværkulturelle og Regionale Studier.

Laland, Kevin N.

2008 “Exploring Gene-Culture Interactions: Insights from Handedness, Sexual Selection and NicheConstruction Case Studies", Philosophical Transactions of the Royal Society B: Biological Sciences 363/1509, 3577-3589. https://doi.org/10.1098/rstb.2008.0132

2017 Darwin's Unfinished Symphony: How Culture Made the Human Mind, Princeton and Oxford: Princeton University Press. https://doi.org/10.1515/9781400884872

Levy, Gabriel

2012 Judaic Technologies of the Word: A Cognitive Analysis of Jewish Cultural Formation, Sheffield \& Bristol: Equinox Publishing, Ltd.

Lied, Liv I.

2012 "Religious Change and Popular Culture with a Nod to the Mediatization of Religion Debate", in Stig Hjarvard \& Mia Lövheim, eds., Mediatization and Religion: Nordic Perspectives, Göteborg: Nordicom, 183-201.

2013 "Manuscript culture and the myth of golden beginnings", in Knut Lundby, ed., Religion across Media. From Early Antiquity to Late Modernity, New York: Peter Lang, 54-70.

Liénard, Pierre \& Jesper Sørensen

2013 "Tools for Thought: The Ritual Use of Ordinary Tools", in Armin W. Geertz, ed., Origins of Religion, Cognition and Culture, Durham: Acumen Publishing Limited, 341-364.

Litt, Carole J.

1986 "Theories of Transitional Object Attachment: An Overview", International Journal of Behavioral Development 9, 383-399. https://doi.org/10.1177/016502548600900308

Lombard, Marlize \& Miriam Noël Haidle

2012 "Thinking a Bow-and-Arrow Set: Cognitive Implications of Middle Stone Age Bow and StoneTipped Arrow Technology", Cambridge Archaeological Journal 22/2, 237-264. https://doi.org/10.1017/S095977431200025X

Lundager Jensen, Hans J.

2005 "Moses og bodysnatchernes invasion (Durkheim, kognition og Deuteronomium)", Collegium Biblicum Årsskrift 2005, 33-45. https://doi.org/10.7146/rt.v0i46.1883

2011 "Religionshistorie og aksetid: Om Robert Bellahs udkast til en evolutionær religionshistorie", 
Religionsvidenskabeligt Tidsskrift 56, 5-22. https://doi.org/10.7146/rt.v0i56.4209

2020 "Religion og medier. Et religions- og teologihistorisk perspektiv", i Kjeld S. Nielsen \& Sanne B.

Thøisen, eds., Midt i en medietid. Digitalisering og medialisering i religion, filosofi og kunst.

Frederiksberg: Eksistensen, 23-34.

Lundby, Knut, ed.

2013 Religion across Media. From Early Antiquity to Late Modernity, New York: Peter Lang. https://doi.org/10.3726/978-1-4539-1085-6

Lynch, Gordon, ed.

2007 Between Sacred and Profane: Researching Religion and Popular Culture, London: I.B. Tauris.

2011 "What Can We Learn from the Mediatisation of Religion Debate?" Culture and Religion 12/2, 203210. https://doi.org/10.1080/14755610.2011.579714

Lynch, Gordon, Jolyon Mitchell \& Anna Strhan, eds.

2011 Religion, Media and Culture: A Reader, London: Routledge.

Lyon, David

2000 Jesus in Disneyland. Religion in Postmodern Times, Cambridge: Polity Press.

Lövheim, Mia

2011 "The Mediatisation of Religion. A Critical Appraisal", Culture and Religion 12/2, 111-117. https://doi.org/10.1080/14755610.2011.579715

Mahan, Jeffrey

2014 Media, Religion and Culture - An Introduction, London: Routledge. https://doi.org/10.4324/9781315777061

Malafouris, Lambros

2008 "Between Brains, Bodies and Things: Tectonoetic Awareness and the Extended Self", Philosophical Transactions of the Royal Society B. Biological Sciences 363, 1993-2002. https://doi.org/10.1098/rstb.2008.0014

Maryanski, Alexandra

1992 "The Last Ancestor: An Ecological-Network Model on the Origins of Human Sociality", Advances in Human Ecology 2, 1-32.

1993 "The Elementary Forms of the First Proto-Human Society: An Ecological/Social Network Approach", Advances in Human Evolution 2, 215-241.

1995 "African Ape Social Networks: A Blueprint for Reconstructing Early Hominid Social Structure", in J. Steele \& S. Shennan, eds., Archaeology of Human Ancestry, London: Routledge, 67-90.

2013 "The Secret of the Hominin Mind: An Evolutionary Story", in D. Franks \& J. H. Turner, eds., Handbook of Neurosociology, New York: Springer, 257-287. https://doi.org/10.1007/978-94-007-4473-8_18

2018 Émile Durkheim and the Birth of the Gods: Clans, Incest, Totems, Phratries, Hordes, Mana, Taboos, Corroborees, Sodalities, Menstrual Blood, Apes, Churingas, Cairns, and Other Mysterious Things, New York \& London: Routledge. https://doi.org/10.4324/9780429503993

McLuhan, Marshall

1994 [1964] Understanding Media: The Extensions of Man, New York: McGraw-Hill.

McPherron, Shannon P., Zeresenay Alemseged, Curtis W. Marean, Jonathan G. Wynn, Denné Reed, Denis Geraads, René Bobe \& Hamdallah A. Béarat

2010 “Evidence for Stone-Tool-Assisted Consumption of Animal Tissues before 3.39 Million Years Ago at Dikika, Ethiopia", Nature 466/7308, 857-860. https://doi.org/10.1038/nature09248

Meyer, Birgit

2008 "Religious Sensations: Why Media, Aesthetics and Power Matter in the Study of Contemporary Religion", in Hent de Vries, ed., Religion: Beyond a Concept, New York, 704-723. 
2010 "'There is a Spirit in that Image': Mass-Produced Jesus Pictures and Protestant Pentecostal Animation in Ghana", Comparative Studies in Society and History 52, 100-130. https://doi.org/10.1017/S001041750999034X

2011 "Mediation and Immediacy. Sensational Forms, Semiotic Ideologies and the Question of the Medium", Social Anthropology 19/1, 23-39. https://doi.org/10.1111/j.1469-8676.2010.00137.x

2014 "Mediation and the Genesis of Presence" (reprint of inaugural lecture), with a response on comments by Hans Belting, Pamela Klassen, Chris Pinney, Monique Scheer. An Author Meets Her Critics - Around Birgit Meyer's "Mediation and the Genesis of Presence: Toward a Material Approach to Religion", Religion and Society: Advances in Research 5, 205-254. https://doi.org/10.3167/arrs.2014.050114

Meyer, Birgit, ed.

2009 Aesthetic Formations. Media, Religion and the Senses, New York: Palgrave MacMillan.

Meyrowitz, Joshua.

2001 "Morphing McLuhan: Medium Theory for New Millennium", Proceedings of the Media Ecology Association 2, 8-22.

1994 "Medium Theory", in D. Crowley, and D. Mitchell, eds., Communication Theory Today, Cambridge: Polity Press, 50-77.

1986 No Sense of Place. The Impact of Electronic Media on Social Behavior, New York: Oxford University Press.

Morgan, David

2011 "Mediation or Mediatisation: The History of Media in the Study of Religion", Culture and Religion 12, 137-152. https://doi.org/10.1080/14755610.2011.579716

2012 The Embodied Eye: Religious Visual Culture and the Social Life of Feeling, Berkeley: University of California Press. https://doi.org/10.1525/california/9780520272224.001.0001

2018 Images at Work: The Material Culture of Enchantment, Oxford: Oxford University Press. https://doi.org/10.1093/oso/9780190272111.003.0003

Morris, P.H., V. Reddy \& R.C. Bunting

1995 “The Survival of the Cutest: Who's Responsible for the Evolution of the Teddy Bear?" Animal Behaviour 50/6, 1697-1700. https://doi.org/10.1016/0003-3472(95)80022-0

Navarrete A.F., S.M. Reader, S.E. Street, A. Whalen \& K.N. Laland

2016 "The Coevolution of Innovation and Technical Intelligence in Primates", Philosophical Transactions of the Royal Society B 371: 20150186. https://doi.org/10.1098/rstb.2015.0186

Nelson, Victoria

2001 The Secret Life of Puppets, Cambridge \& London: Harvard University Press.

Nielsen, Trine Kellberg, Casper Andersen, Alexandra R. Kratschmer \& Mathias Clasen, eds.

2019 Menneske, kultur, evolution - et biokulturelt perspektiv, Aarhus: Aarhus Universitetsforlag.

Nowell, April

2016 "Childhood, Play and the Evolution of Cultural Capacity in Neanderthals and Modern Humans", in Miriam N. Haidle, Nicholas J. Conard \& Michael Bolus, eds., The Nature of Culture: Based on an Interdisciplinary Symposium 'The Nature of Culture', Tübingen, Germany, Dordrecht: Springer Verlag, 87-97. https://doi.org/10.1007/978-94-017-7426-0_9

Ong, Walter

1996 Orality and Literacy, London: Routledge.

Partridge, Christopher

2004-2006 The Re-enchantment of the West: Alternative Spiritualities, Sacralization, Popular Culture and Occulture, Vol. I \& II, London: T\&T Clark.

Pernet, Henry, ed. 
1992 Ritual Masks: Deceptions and Revelations, oversat af Laura Grillo, Columbia: University of South Carolina Press.

Petersen, Anders Klostergaard

2015 "Religionsvidenskab og historie", in Armin W. Geertz \& Tim Jensen, eds., Religionsforskningen før og $n u$ - Nyere tid, København: Gyldendal, 246-282.

2017 "The Indispensability of Cognitive Science for a Genuine History of Religion", in Luther H. Martin \& Donald Wiebe, eds., Religion Explained? The Cognitive Science of Religion after TwentyFive Years, London: Bloomsbury Academic, 97-104.

2019 “Om Jan Assmanns aksetidsforståelse, kosmos-religion og biologisk og kulturel evolution i kultur- og religionshistorien", Tidsskriftet Fønix 2019, 66-106.

Petzinger, Genevieve von

2016 The First Signs: Unlocking the Mysteries of the World's Oldest Symbols, New York: Atria Books.

Pierroutsakos, Sophia L. \& Judy S. DeLoache

2003 “Infants' Manual Exploration of Pictorial Objects Varying in Realism", Infancy 4/1, 141-156. https://doi.org/10.1207/S15327078IN0401_7

Renfrew, Colin, Chris Frith \& Lambros Malafouris, eds.

2008 The Sapient Mind: Archaeology Meets Neuroscience, (Philosophical Transactions of the Royal Society B: Biological Sciences, 2008; genoptrykt), Oxford \& New York: Oxford University Press, 2009.

Reilly, Kara

2011 Automata and Mimesis on the Stage of Theatre History, Basingstoke \& New York: Palgrave Macmillan. https://doi.org/10.1057/9780230347540

Richardson, Kathleen

2016 “Technological Animism: The Uncanny Personhood of Humanoid Machines", Social Analysis 60/1, 110-128. https://doi.org/10.3167/sa.2016.600108

Richerson, Peter J. \& Robert Boyd

2005 Not by Genes Alone: How Culture Transformed Human Evolution, Chicago \& London: The University of Chicago Press. https://doi.org/10.7208/chicago/9780226712130.001.0001

Riede, Felix Riede, Niels N. Johannsen, Anders Høgberg, April Nowell \& Marlize Lombard

2018 "The Role of Play Objects and Object Play in Human Cognitive Evolution and Innovation", Evolutionary Anthropology 27, 46-59. https://doi.org/10.1002/evan.21555

Riede, Felix \& Matthew J. Walsh

2019 "Kulturel evolution", in Trine Kellberg Nielsen, Casper Andersen, Alexandra R. Kratschmer \& Mathias Clasen, eds., Menneske, kultur, evolution - et biokulturelt perspektiv, Aarhus: Aarhus Universitetsforlag, 46-59.

Rodríguez-Vidala, Joaquín et al.

2014 "A Rock Engraving Made by Neanderthals in Gibraltar", Proceedings of the National Academy of Sciences 111/37, 13301-13306. https://doi.org/10.1073/pnas.1411529111

Roepstorff, Andreas

2008 "Things to Think With: Words and Objects as Material Symbols", Philosophical Transactions of the Royal Society B. Biological Sciences 363, 2049-2054. https://doi.org/10.1098/rstb.2008.0015

Saler, Michael.

2012 As If: Modern Enchantment and the Literary Prehistory of Virtual Reality, Oxford: Oxford University Press.

Schjødt, Jens Peter

2004 "Definitionsproblemer i forhold til begrebet religion", in Armin W. Geertz, Hans J. Lundager Jensen \& Jens Peter Schjødt, eds., Det brede og det skarpe. Religionsvidenskabelige studier. En gave til Per Bilde på 65 års dagen, Aarhus: Forlaget Anis, 13-22. 
Sinding Jensen, Jeppe

2010 "Doing It the Other Way Around: Religion as a Basic Case of 'Normative Cognition'”, Method and Theory in the Study of Religion 22/4, 322-329. https://doi.org/10.1163/157006810X531102

2013 "Normative Cognition in Culture and Religion", Journal for the Cognitive Science of Religion 1/1, 47-70. https://doi.org/10.1558/jcsr.v1i1.47

2014 "How Institutions Work in Shared Intentionality and 'We-Mode' Social Cognition", Topoi. An International Review of Philosophy 33/2, 1-12. https://doi.org/10.1007/s11245-015-9306-7

Smith, Frank

1985 “A Metaphor for Literacy: Creating Worlds or Shunting Information?" in David R. Olson, Nancy Torrance \& Angela Hildyard, eds., Literacy, Language, and Learning: The Nature and Consequences of Reading and Writing, Cambridge: Cambridge University Press, 195-213.

Spuhler, J. N. \& Leslie A. White, eds.

1959 The Evolution of Man's Capacity for Culture, Detroit: Wayne State University Press.

Street, Brian V.

1984 Literacy in Theory and Practice, Cambridge: Cambridge University Press.

Stolow, Jeremy

2005 "Religion and/as Media", Theory, Culture and Society 22, 119-145. https://doi.org/10.1177/0263276405054993

Stout, Dietrich \& Thierry Chaminade

2012 "Stone Tools, Language and the Brain in Human Evolution", Philosophical Transactions of the Royal Society B. Biological Sciences 367, 75-87. https://doi.org/10.1098/rstb.2011.0099

Stout, Dietrich, Nicholas Toth, Kathy Schick \& Thierry Chaminade

2008 "Neural Correlates of Early Stone Age Toolmaking: Technology, Language and Cognition in Human Evolution", Philosophical Transactions of the Royal Society B. Biological Sciences 363, 19391949. https://doi.org/10.1098/rstb.2008.0001

Sørensen, Jesper

2004 "Religion, Evolution, and an Immunology of Cultural Systems", Evolution and Cognition 10/1, 61-73.

Sørensen, Jesper \& Kristoffer L. Nielbo

2015 "Kognitiv religionsvidenskab", in Armin W. Geertz \& Tim Jensen, eds., Religionsforskningen før og nu - Nyere tid, København: Gyldendal, 469-509.

Tomasello, Michael

1999 The Cultural Origins of Human Cognition, Cambridge \& London: Harvard University Press

Truit, E. R.

2015 Medieval Robots: Mechanism, Magic, Nature, and Art, Philadelphia: University of Pennsylvania Press. https://doi.org/10.9783/9780812291407

Turner, Jonathan $\mathrm{H}$.

2000 On the Origins of Human Emotions: A Sociological Inquiry into the Evolution of Human Affect, Stanford: Stanford University Press.

Turner, Jonathan H., Richard Machalek \& Alexandra Maryanski, eds.

2013 Handbook on Evolution and Society: Toward an Evolutionary Social Science, Boulder \& London: Paradigm Publishers.

Turner, Jonathan H. \& Alexandra Maryanski

2008 On the Origin of Societies by Natural Selection, Boulder \& London: Paradigm Publishers.

Turner, Jonathan H., Alexandra Maryanski, Anders Klostergaard Petersen \& Armin W. Geertz

2018 The Emergence and Evolution of Religion: By Means of Natural Selection, New York \& London: Routledge. https://doi.org/10.4324/9781315111995 
Uthmeier, Thorsten

2016 "Neanderthal Utilitarian Equipment and Group Identity: The Social Context of Bifacial Tool Manufacture and Use", in Miriam N. Haidle, Nicholas J. Conard \& Michael Bolus, eds., The Nature of Culture: Based on an Interdisciplinary Symposium 'The Nature of Culture', Tübingen, Germany, Dordrecht: Springer Verlag, 65-77. https://doi.org/10.1007/978-94-017-7426-0_7

Voskuhl, Adelheid

2013 Androids in the Enlightenment: Mechanics, Artisans, and Cultures of the Self, Chicago \& London: The University of Chicago Press. https://doi.org/10.7208/chicago/9780226034331.001.0001

Wang, Shensheng, Scott O. Lilienfeld \& Philippe Rochat

2015 “The Uncanny Valley: Existence and Explanations", Review of General Psychology 19/4, 393-407. https://doi.org/10.1037/gpr0000056

Washburn, S. L.

1959 "Speculations on the Interrelations of Tools and Biological Evolution", in J. M. Spuhler, \& L.A. White, eds., The Evolution of Man's Capacity for Culture, Detroit: Duke University Press, 21-31.

Wood, Gaby

2002 A Magical History of the Quest for Mechanical Life, London: Faber and Faber.

Woodhead, Linda

2004 An Introduction to Christianity, Cambridge: Cambridge University Press.

Woodhead, Linda and Paul Heelas, eds.

2000 Religion in Modern Times: An Interpretive Anthology, Oxford: Blackwell.

Wynn, Thomas \& Frederick L. Coolidge

2004 "The Expert Neandertal Mind", Journal of Human Evolution 46, 467-487. https://doi.org/10.1016/j.jhevol.2004.01.005

Zilhão, João et al.

2010 "Symbolic Use of Marine Shells and Mineral Pigments by Iberian Neandertals", Proceedings of the National Academy of Sciences 107/3, 1023-1028. https://doi.org/10.1073/pnas.0914088107

Laura Feldt, lektor, ph.d. Afdeling for Religionsstudier, Institut for Historie, Syddansk Universitet Armin W. Geertz, professor emeritus, dr.phil. Afdeling for Religionsvidenskab, Institut for Kultur og Samfund, Aarhus Universitet 